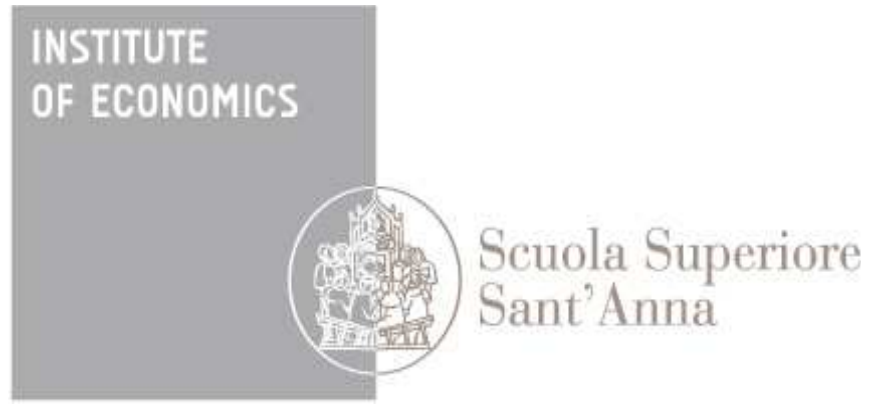

LEM | Laboratory of Economics and Management

Institute of Economics

Scuola Superiore Sant'Anna

Piazza Martiri della Libertà, 33 - 56127 Pisa, Italy ph. +3905088.33 .43$

institute.economics@sssup.it

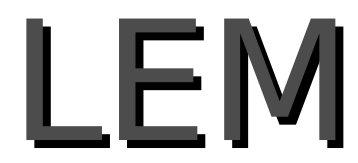

Working Paper Series

\title{
Making the Eurozone work: a risk-sharing reform of the European Stability Mechanism
}

\author{
Giovanni Dosi a \\ Marcello Minennab \\ Andrea Roventini ${ }^{a, c}$ \\ Roberto Violi ${ }^{d}$
}

${ }^{a}$ Institute of Economics, Scuola Superiore Sant'Anna, Pisa, Italy

${ }^{b}$ CONSOB, Rome, ly CONSOB, Rome, Italy

c OFCE-Sciences Po, Nice, France

${ }^{\mathrm{d}}$ Bank of Italy, Rome, Italy 


\section{Making the Eurozone work: \\ a risk-sharing reform of the European Stability Mechanism}

(PRELIMINARY DRAFT)

(Giovanni Dosi ${ }^{\bowtie}$, Marcello Minenna*, Andrea Roventini ${ }^{+}$, Roberto Violi” $^{\#}$

This work presents an original proposal for the reform of the Eurozone architecture according to an approach based on risk sharing (aiming to reach in the long-term the mutualization of public debt). The proposal envisages a new role for the European Stability Mechanism (ESM) which should gradually become the guarantor of the public debts of the EMU. In this way, the new ESM would support the full transition from national debts to a single Eurozone public debt (e.g. Eurobonds) with a single yield curve for all countries. Our proposal would benefit both core and peripheral EMU countries. Indeed, the riskiest countries, which would gain from the ESM conditional debt guarantee, should give up the possibility of redenominating their national debt and would pay to the ESM the corresponding market price of the guarantee. This would strengthen the capital endowment of the ESM and also allow it to use its leverage capability to support the realignment of the economic cycles of the different countries through profitable public investment plans concentrated in the weakest regions of the EMU. Such plans would be coordinated and implemented by the European Union. After a transition period, our Insurance Fund proposal would contribute to a much more resilient monetary union, with a European fiscal policy and debt. Admittedly this proposal presupposes a political consensus at the EU level to reinterpret to the no bailout rule enshrined in the treaties so that risk sharing institutions implemented with fairly priced insurance scheme can be allowed. New risk sharing institutions will foster a common vision of belonging to the same federal, political union in the making, the only one compatible with the abdication of fiscal sovereignty by national governments .

\footnotetext{
$\tilde{\text { I }}$ Full Professor of Economics at the Scuola Superiore Sant'Anna, Pisa (Italy), E-mail: giovanni.dosi@santannapisa.it

* Director, Consob, E-mail: marcello@minenna.it

+ Full Professor of Economics at the Scuola Superiore Sant'Anna, Pisa (Italy) and OFCE, Sciences Po, Nice (France). E-mail: andrea.roventini@santannapisa.it

氧:\#Senior Director, Banca d'Italia, E-mail: roberto.violi1@gmail.com

$\boldsymbol{\gamma}^{\circ}$ The views and opinions here expressed are those of the authors and do not necessarily reflect the official policy or position of the opinions of the institutions to which they belong.
} 
KEYWORDS: Sovereign Debt, Risk-Sharing, Insurance Fund, ESM, ECB, $O M T, Q E, C D S$ spread, Investments' Multiplier, Bond-Market Discipline, Safe Asset

$$
\text { (J.E.L.: E02, G01, H12, H63) }
$$

“Those Who Reap The Benefits Must Bear The Costs”
(Walter Eucken, AS QUOTED BY Jens WeidManN, 2016)

\section{INTRODUCTION}

The issue of Eurozone overhauling is gaining more and more attention in relation with key deadlines for the transposition of the Fiscal Compact and of the European Stability Mechanism (ESM) into the EU legislative framework. Both were born in 2012 as inter-governmental agreements aimed at improving Eurozone resilience according two arms: on the one hand the Fiscal Compact would have improved budgetary discipline in "rogue" countries, and on the other hand the ESM would have acted as a safety net for Eurozone members.

A reality check reveals that both agreements have fundamental failures. The Fiscal Compact - along with the Six Pact of late 2011 - has significant procyclical side effects due to the excessive limit on public spending imposed to most fragile economies, and the ESM is only in theory a sovereign bailout fund for the Euro area because of an unbalanced financial structure, a governance with a level of discretion which may hamper full accountability to all its members and an intervention policy that is bounded to cases of overt crises.

The proposals for the revision of the Eurozone architecture currently under discussion at the EU institutional level do not show a real awareness of these failures and remain in their essence consistent with the view that the fragility of the peripheral countries must be managed with risk reduction and risk segregation. Apart from small scale initiatives towards some form of fiscal union - such as the creation of a stabilization function of the Eurozone and a European "rainy days" fund - the proposals presented by Germany, by the European Commission, by a group of 14 French-German economists (BénassyQuéré, et al., 2018), and by the Finance Ministers of 7 Northern Eurozone countries $^{\circ}$ fall short of addressing in a convincing manner the key problems of the Euro area (Herr, Priewe and Watt, 2017, De Grauwe, 2013).

The main implication of current Eurozone economic problems - as many predicted, even prior the departure of the European Monetary Union (Goodhart, 1997, Goodley, 1997) - is the worsening of difficulties in macroeconomics adjustments because the crucial complementarity between the fiscal, taxraising and spending authority on the one hand and monetary policy authority on the other hand is not working: national fiscal policy and single monetary policy for the Euro area as a whole cannot achieve the level of coordination

TDenmark, Estonia, Finland, Ireland, Latvia, Lithuania, the Netherlands and Sweden. 
when this is mostly needed, especially in time of recessions and/or financial crisis.. This introduces a strong constraint on national Governments in their attempt to stabilize their economy by lowering taxes and increasing spending in difficult times, as they cannot rely on the support from the central bank hence remaining exposed to financial markets' vagaries which may prove very unfavorable. The final outcome - especially in adverse scenarios - is that, in order to safeguard the solvency, government may be forced to adopt more deflationary stance than desirable.

The present work illustrates an original proposal for the reform of the Eurozone according to an approach based on risk-sharing principles which entail the creation of a supranational Insurance Fund with the price of risk determined by the capital markets (Minenna and Aversa, 2018). The proposal envisages a new role for the ESM which should gradually become the guarantor of the public debts of the Euro bloc countries up to achieve the full transition from national debts to a single Eurozone public debt with a single sovereign yield curve and, thus, reaching the goal of implementing a uniform sovereign debt price for all member States.

In exchange for the conditional guarantee provided, the ESM would be entitled to new contributions by risky countries for an amount corresponding to the market price of the guarantee. Additional equity capital to protect against unexpected loss can also be called upon to risky countries. This would strengthen the capital endowment of the Stability Mechanism consequently increasing its ability to borrow on the financial markets without having to increase its leverage and, therefore, maintaining a low risk profile under normal as well as stressed market conditions. Obviously under extremely adverse scenarios the ESM could rely on the possibility to increase its leverage according to standard market practices being eventually backed by the ECB as already happened in the recent years.

In particular, apart from extremely adverse scenarios, the new ESM could issue investment-grade liabilities appropriately spread over the various maturities of the term structure. Along with guaranteed Govies, these ESM-issued liabilities would create a genuine Eurozone safe asset eventually available to the capital markets: this would correct one of the main anomalies of the European Monetary Union. We refer to the fact that, since the eruption of the global financial crisis, the role of Eurozone safe asset has been improperly held by the German government bonds: their under-sized outstanding notional with respect to the financial and economic dimension of the Euro area implies a systematic scarcity of safe assets which contributes to drive Bund yields on the negative territory even on the medium maturities. This role - albeit reflecting a matter of fact (i.e. the outstanding credit worthiness of Germany with respect to its partners) - stems from the combination of the above mentioned Eurozone 
architectural fragilities coupled with the risk segregation strategy that cores countries have advocated since the beginning of this decade.

The proceeds from the placement of its liabilities (or parts of them in extremely adverse scenarios) would allow the reformed Stability Mechanism to finance safe and valuable investment projects concentrated in the weakest regions of the Euro bloc. This would crucially promote the re-alignment and harmonization of the economic cycles across member countries. Indeed, the provision for a strict proportionality between the premiums paid for the guarantee by risky countries and the ESM-funded fixed capital formation within the same countries could eventually remedy the harmful pro-cyclical side effects of the Fiscal Compact which has forced many governments to freeze de facto investment spending and, thus, to hamper growth.

On the medium-long term the reconciliation of the roles of public debt guarantor and project financer within the same supranational institution would lead to the natural transition to a single Eurozone's Finance Minister appointed for the management of a federal budget (with well-defined federal revenues) and a federal debt and entitled to rely on a cooperative monetary policy by the European Central Bank. Prospectively, once completed the phase-in period, the ESM could gradually replace its covenant on national public debts with a direct issuance of Eurozone supranational securities (Eurobonds). In the lively policy debate over the sovereign debt crisis in Europe how to "convert" public debt in the Eurozone into "Eurobonds" has been a widely discussed proposal. This proposal has been supported at political level among others by Monti (2010), Tremonti and Juncker (2010) and elaborated at a more technical level in De Grauwe and Moesen (2009), Boonstra (2010), Eijffinger (2010), Depla and Weizsacker (2010), Baglioni and Cherubini (2012), Claessens et al. (2012), Favero and Missale (2012).

Admittedly our proposal presupposes a political consensus at the EU level to reinterpret the recurrent reference to the no bailout rule enshrined in the treaties - a risk-sharing mechanism based on market prices being consistent with the no-bail-out principle - and to favor a common vision of belonging to the same federal reality, the only one compatible with the abdication of fiscal sovereignty by national governments. More broadly our proposal requires a call for more coordinated behavior in the EU in taking preliminary steps towards some, admittedly loose, form of fiscal union with limited centralization which nonetheless entails further institution building. Many scholars and practitioners have proposed a Eurozone Treasury (Semmler and Young, 2017). In fact, both the presidents of the German and French Central Banks, Jens Weidmann and Francois Villeroy de Galhau, have suggested a Euro-treasury (Süddeutsche Zeitung, 8.2.2017). 


\section{EUROZONE FRAGILITY: WRONG CULPRITS AND EASY SCAPEGOATS}

Economic and financial integration has been at the core of the European unification process since its very beginning. The establishment of the European Monetary Union (EMU) and the harmonization of monetary policy across the Member States under the umbrella of the European Central Bank (ECB) was a milestone towards the goal of a fully integrated Single European Market. The 2008 financial crisis and following Sovereign Debt Crisis did provide strong evidence that European economic and financial markets are far from being perfectly integrated. The capital outflow from the Eurozone peripheral countries to the core countries illustrated a capital retrenchment in response to a sharp increase in aggregate risk. The crisis period made clear that further advancements in the integration of the European capital markets and institutions are necessary to complement the EMU. In the evolution of panEuropean markets architecture Banking and Capital Markets Union are designed to achieve a more diversified financial system through fully integrated banking and capital markets across all EU members with the goal of ensuring greater financial stability and improved funding opportunities for European companies.

While the combination of EMU with Banking and Capital Market Unions will provide a strong European market infrastructure, it remains unclear if the EU is able to progress towards a Fiscal Union. In the absence of a Fiscal Union, a true single market for capital cannot be achieved as fiscal spending will continue to depend on the solvency and fiscal policies of the respective sovereign. The overwhelming empirical evidence shows that risk-sharing in the euro area is significantly lower compared to similar federations such as the United States (e.g. Furceri and Zdzienicka, 2013). According to Milano and Reichlin (2017) the lower degree of risk-sharing in the Eurozone is attributable to the absence of direct transfers from Federal Government (vis-à-vis 20 percentage points in the US) and substantially lower factor income (some 25 percentage points larger in the US; this latter is a proxy for the efficiency/integration of financial markets; loannou and Schaefer, 2017). However, more integrated capital markets foster network effects and increase the mobility of capital facilitating a withdrawal of funds in times of crisis. Financial markets "imperfections" - such as contagion effects and herding behavior - in combination with self-fulfilling prophecies can contribute to the surge of massive financial instability when large borrowers such as Sovereign States - are subject to roll-over risk as a result of changes in market participants credit risk perception (De Grauwe and Ji, 2013).

A large part of the debate on Eurozone overhauling moves from the shared need to overcome substantial differences between member States and increase the resilience of the Euro bloc in the event of new crises. However, there is no consensus on the causes of differences and imbalances nor consequently - on the reforms to be adopted. 
According to a view held by many commentators fiscal recklessness of Southern European countries is the basic cause of their excessive indebtedness, often significantly higher than the $60 \%$ optimal threshold enshrined in the Maastricht Treaty. In turn, the excessive size of the debt compared to that of the economy causes excessive riskiness which - at the peak of the Sovereign Debt Crisis (2010-2012) - has spilled up the risk premium required by the markets to finance "rogue" countries and which was reflected in the significant widening of sovereign yield spreads with respect to the Bund. However, as argued forcefully by Di Cesare et al. (2012), previous analyses and their new evidence suggest that during the Sovereign Debt Crisis in the Eurozone government bond spreads for several countries have increased to levels that were well above those that could be justified on the basis of fiscal and macroeconomic fundamentals. Among the possible reasons for this gap, their analysis singles out the increasing perceived risk of a break-up of the Eurozone, as resulting also from other technical analyses focused on market indicators of the redenomination risk (Minenna, 2014).

According to a view widely debated in Germany and other core countries ECB extraordinary interventions - with the announcement of the Outright Monetary Transactions (OMTs) and, later, with the Quantitative Easing (QE) - have dampened sovereign spreads and artificially altered the perception of the sovereign risk of the peripheral countries by financial markets. These interventions - in particular the QE (OMTs have never been enforced) - have realized a surreptitious monetary financing which violates the ECB Statute. For this reason the end of the $\mathrm{QE}$ and proposals for risk reduction aimed at peripheral countries and based on strict domestic reforms, regardless of their manifest pro-cyclical contraindications, are seen as the only way forward for the Eurozone. The ESM - turned into a European equivalent of the International Monetary Fund - should take over from the European Commission (considered too accommodating with the periphery) as a fiscal watchdog to oversee the compliance of the budgetary policies of all member States. New solutions to carry forward the strategy of risk segregation pursued since the outbreak of the crisis are also suggested: namely, private investors should participate in any losses on government bonds and, thus, recommend the creation of a Sovereign Debt Management Mechanism. The SDMM should provide for an automatic maturities extension of public debts above given thresholds in terms of GDP and, in any case, as necessary condition to get access to the ESM financial support. Since debt re-profiling could be not enough, Germany also spurs the replacement of current model-CACs with new Creditor Participation Clauses (CPCS) which should simplify the achievement of the majorities required for early debt restructurings and, at the same time, prevent Govies' redenomination in a new national currency in the event of exit from the euro. 
Italy, in particular, appears to be the main concern. Not only for its high public debt (over 2 times the Maastricht threshold in GDP terms) but also for its large Target 2 deficit which some commentators consider a substitute bailout.

Yet such a questionable reconstruction/interpretation of Eurozone sovereign crisis events ignore a number of facts which are the consequences of substantial lack of risk sharing in the EMU fabric. Large gaps and unbalances across Eurozone members were fostered by risk segregation, the same which handed over to the Bund the super-exclusive status of "safe haven" allowing the core countries public and private sectors to finance domestic economic activity at extremely low costs and to enjoy undue competitive advantages.

During the Sovereign Debt Crisis of 2010-2012 risk segregation has occurred in the form of massive deleveraging of exposures in peripheral Govies by German (and French) banks, which has led to the de-facto "re-nationalization" of public debts of Eurozone's periphery within the balance sheets of the domestic banking sector.

Later, the Quantitative Easing has realized a similar nationalization within National Central Banks (NCBs). Indeed, the assets purchase program announced by the ECB on January 2015 relies almost completely on risk segregation: NCBs borrow money from the ECB to purchase sovereign bonds of their respective governments. Consequently, they are exposed to the credit risk of their own country, whereas the ECB retains its creditor's rights towards the NCBs even in the event of sovereign defaults. In addition, bonds' purchases within the QE are allocated according to the ECB's capital key: Germany gets the largest share of purchases which partly explains the abnormal negative yields on Bunds even in the medium-long term and the consequent easy reduction of the Germany's public debt servicing cost (Minenna, 2016).

Now that the deleveraging of core countries banking systems has been accomplished, high in the agenda are policy proposals pushing for the introduction of concentration limits on banks' exposures in Govies although it is quite evident that this would re-ignite yield spreads and make unsustainable the public debt of peripheral countries. Unsustainability that, if such proposals were accepted, would trigger debt reprofiling (or even restructuring) and would force countries like Italy to leave capital markets and lose fundamental assets, starting from gold reserves.

\section{EUROZONE FRAGILITY: AVOIDING FAUX PAS AND/OR TINKERING WITH FEEBLE SOLUTIONS}

In December 2017 the European Commission presented a proposal for a reform of the Eurozone that resumes main Germany's warhorses and gives timid room for anti-cyclical measures at the level of the European budget, also through the 
possible introduction of a stabilization function. In January 2018 a group of 14 influential French-German economists has released a proposal that recommends the creation of a European safe asset. This latter recommendation stems from a proposal originally presented by a group of economists (Euronomics Group, 2011) which basically advice the issuance of European Safe Bonds (ESBies) backed by a collateral portfolio of Eurozone Govies. Basically the ESBies proposal provides for the pooling and tranching of cross-border portfolios of national sovereign bonds and it was welcome by the European Systemic Risk Board (Brunnermeier et al., 2016) which defined it as an interesting and attractive approach that could contribute to the ESRB's objective. In May 2018, the European Commission released on its website a proposal for regulation regarding ESBies (European Commission, 2018).

Despite being marketed as a solution to the sovereign-bank doom loop (along with concentration limits) and to significantly increase the supply of safe assets within the Euro area, the proposal amounts to nothing short of a remake of sovereign spreads. Indeed, although the authors claim that junior securities would be absorbed by international speculative investors, it is more likely than not that junior tranches would be purchased mainly by the banks of Eurozone periphery, whereas senior tranches (i.e. the "safe asset") would go to the banks of North European countries. In short, such great effort to create a pool of safe assets could end up maintaining the status quo or, even worsening it by multiplying the number of spreads within the Eurozone. In addition to differences between yields on Govies, there would also be those between the ESBies' tranches with different subordination degrees and those between tranches and stand-alone Govies, at the risk of making the refinancing conditions more burdensome for the Southern governments of the Euro bloc (Minenna, 2017).

Also, the working hypotheses of the ESBies proposal are quite optimistic: in particular, the behavior of the correlations between the default events of the member countries of the Eurozone is significantly underestimated; conversely, if this key point was taken into account, the proposal would imply issuing junior tranches of very large thickness and, coherently, the supply of safe assets would be significantly reduced limiting the actual benefits compared to the noESBies scenario.

Ultimately, such proposals overlook the fact that stability cannot be achieved by stubbornly maintaining distinctions and preserving privileges which were largely due to the distortions of the Euro area and to the strategy of risk segregation adopted by core countries.

The proposal to create a European "safe asset" certainly stems from a noble thought but, in practice, the application of securitization techniques to Govies would safeguard the discrimination between the center and the periphery of the Euro area. German Bunds - under the new label of "senior ESBies" - would 
continue to be a "safe haven" whereas Italian BTPs and Spanish Bonos - under the new label of "junior ESBies" - would remain risky assets, discriminated by markets and likely also by the ECB'. Market "segmentation" and roll-over risk in the Eurozone would basically survive intact and with it its financial fragility.

This fragility is derived from the loss of control on monetary policy at the country level which prevents single EMU members from increasing inflation through expansionary monetary policies to ensure the payment of sovereign debt denominated in the domestic currency. While investors may incur losses through inflation, the losses realized in the case of a government default might be more severe. Sovereign bonds denoted in the domestic currency in the country were never a truly risk-free asset, as they are driven by both inflation and exchange rate risks, however these risks to a certain degree counteracted the likelihood of a full default establishing a safe asset as financing tools to standalone countries. As member States of the EMU cannot guarantee the payment of their debt at maturity through issuing their own money, they do not have access to a safe asset as a financing source and thus become more vulnerable to market fluctuations. This is the unique and existential risk of Euro area membership: monetary union exposes its member states to an insolvency risk which is absent for similar countries which have a national currency. When a country adopts the euro, its debt is redenominated from the national currency into the euro. Thus, member States are in a similar situation as emerging market economies which can only borrow in a foreign currency ('original sin'). In a crisis they can no longer rely on the support of their national central bank. In such a 'gold standard without gold' (Blyth 2013, p. 184) financial markets "can force countries into a bad equilibrium characterized by increasing interest rates that trigger excessive austerity measures, which in turn lead to a deflationary spiral that aggravates the fiscal crisis." (De Grauwe, 2015). This specific risk is aggravated by an easy exit option that the single currency provides for investors. If, for example, a Japanese pension fund is no longer willing to hold Japanese government bonds and decides to hold US treasuries instead, it is confronted with a currency risk. For institutional investors that are required to hold safe assets, this 'currency wall' is difficult to surmount. Within the euro area this wall has been removed so that investors can exchange domestic bonds into bonds of other member States without an exchange rate risk (Bofinger, 2018).

The experience of the last 16 years shows that Eurozone is a more crisis-prone regime than other major currency areas like the US, Japan, or the UK. This is mainly due to its hybrid institutional architecture which relies primarily on intergovernmental and supranational elements. While monetary policy is fully integrated under the aegis of the ECB, 19 national governments are

TCherubini and Violi (2015) for an earlier thorough explanation as to why securitization of bond portfolios cannot deliver (credit) risk mutualization. In essence, creating a pool of "risk-free" assets does not necessarily require nor imply any risk mutualization among bond issuers. 
responsible for the Eurozone's fiscal policy. However, rather than being a victim of a 'design failure', the Eurozone can be better regarded as an unfinished building that needs to be completed with more coordination and more political integration.

This diagnosis can lead to two different solutions. Some economists believe that the insolvency risk is unavoidable. Therefore, institutional procedures should be developed for dealing with future insolvencies, such as some form of SDMM as mentioned above. The alternative approach is to reduce or even eliminate the insolvency risk of member States by strengthening the supranational features of the Eurozone. Thus, to deal effectively with the insolvency risk we should look for solutions that reduce or even eliminate it; just preparing for a hard landing may not be sufficient to stabilize the Eurozone.

A permanent solution to the insolvency risk problem would be the creation of a European-wide Insurance Fund which would guarantee investors in Eurozone sovereign debt, thereby restoring the paradigm of a truly single currency that requires a monetary union to have a uniform 'price-of-money' across the Eurozone sovereign issuers, a single broadly-based yield curve representative of the interest rate risk of the European Union as a whole. And, at the same time, we have to create the right conditions to ensure that the allocation of risks among member States will converge through policy measures to stimulate growth of the peripheral countries whose economies were deeply hit by the crisis and risk segregation policies undertaken by Eurozone institutions.

Let us see how to achieve these targets by reviewing the architecture of the European Stability Mechanism.

\section{OPEN ISSUES With the CURRENT ESM MACHINERY}

The European Stability Mechanism (ESM) is a crisis resolution mechanism established by the euro area countries. Its mission is to provide financial assistance to ESM Members experiencing or threatened by severe financing problems in order to safeguard the financial stability of the euro area as a whole and of its Member States. The ESM - also known as Eurozone sovereign bailout fund - was established in September 2012 as Eurozone permanent firewall after the sovereign debt crisis, the swap of the Greek public debt, the related default of March 2012 and the crisis of the Spanish banking system of the same year.

The ESM raises funds by issuing debt instruments, which are purchased by institutional investors. The proceeds enable the intergovernmental institution to provide its Members the following types of financial assistance (ESM, 2018): 
- loans to cover their financing needs;

- loans and direct equity injections to recapitalize financial institutions;

- credit lines to be used as precautionary financial assistance;

- primary and secondary debt market purchases of Members' national bonds.

Although the financial commitment of the member States may appear as substantial in absolute terms - a total of 700 billion, however with paid-in capital of some 80 billion euro only - it is relatively small compared to the size of government debt in the area. The ESM residual lending capacity currently stands at about $€ 370$ billion against a total of government debt in the area amounting to some 9.5 trillion euro, about 90 per cent of the area's GDP. According to Balassone et al. (2016), it would have been barely enough to cope with the financial assistance programs launched over 2010-12.

Its architecture faces limits that reflect the will of Northern European countries to segregate risks within the periphery and constrain the ESM effective intervention capacity within an extremely stringent set of rules. The Mechanism can provide financial support to a member country only in case of deep distress and mainly according to a loan-based scheme: the beneficiary country gets access to the different tranches of the aid program only if it has successfully implemented a list of domestic reforms defined in a Memorandum of Understanding (MoU) it has been forced to sign.

The commitment to enact the reforms listed in the MoU comes from the "strict conditionality clause" enshrined in art. 126, par. 3 of the Treaty on the Functioning of the European Union. This paragraph was demanded by Germany as extension/explicitness of the no bailout rule written in art. 125 of the same Treaty - which however admits exceptions in case of financing of common specific projects.

The effective contents of the domestic reforms are not agreed between the ESM and the beneficiary country, but imposed by those who retain the power within the governance of the Stability Mechanism.

Here comes another relevant point: ESM governance does not rely in full on the "democratic" principle of no-discrimination among shareholders. Under the ordinary decision-making procedure every country holds a veto right, but under the emergency procedure only the three largest shareholders - Germany, France and Italy (Figure 1) - retain such right. Not a coincidence that the details and conditions of the aid programs that the ESM has granted to Greece over the last years were de-facto strongly influenced by core countries' policy stance and proposals. 

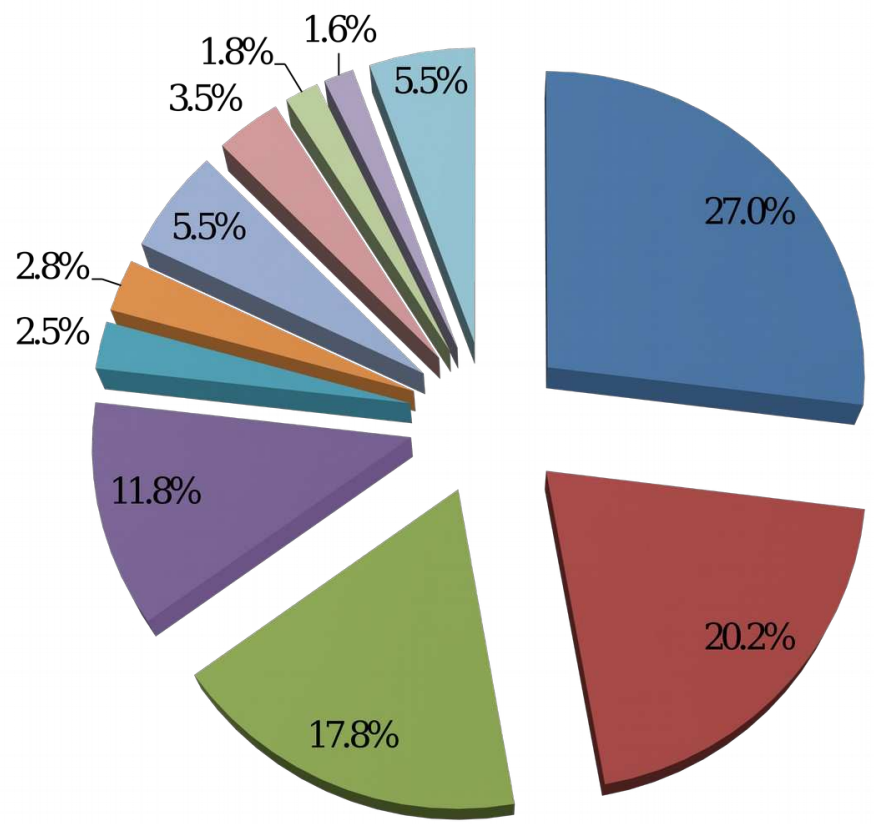

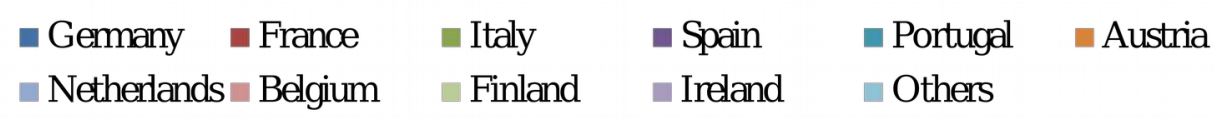

The ESM financial structure has a two-tier configuration with subscribed capital of the Stability Mechanism set at $€ 704.8$ billion, but only the $11.4 \%$ of this amount was already paid-in (€80.55 billion); the remaining are callable shares that member countries have to disburse pro quota upon the request of the ESM to be decided according to the questionable procedure described above. Said differently: in exchange for accepting to become the largest ESM share-holders (and, hence, capital contributors), core countries have purported to limit their effective exposure (e.g. Germany to $€ 21.7$ billion). The remaining is a contingent liability whose disbursement requires the prior approval of the Bundestag. It is a peculiar capital composition: the International Monetary Fund - which has an institutional mandate comparable to the ESM - requires the full payment of the capital share as preliminary condition to join the Fund.

The large gap between subscribed and paid-in capital exposes the Mechanism to the insolvency risk of individual countries at the moment of greatest need, which also explains why the maximum amount of financial support that the ESM is allowed to provide is $€ 500 \mathrm{bn}, € 200 \mathrm{bn}$ lower than the subscribed capital (Figure 2).

\section{Figure 2 - ESM Capital Composition: paid-in shares versus callable shares}




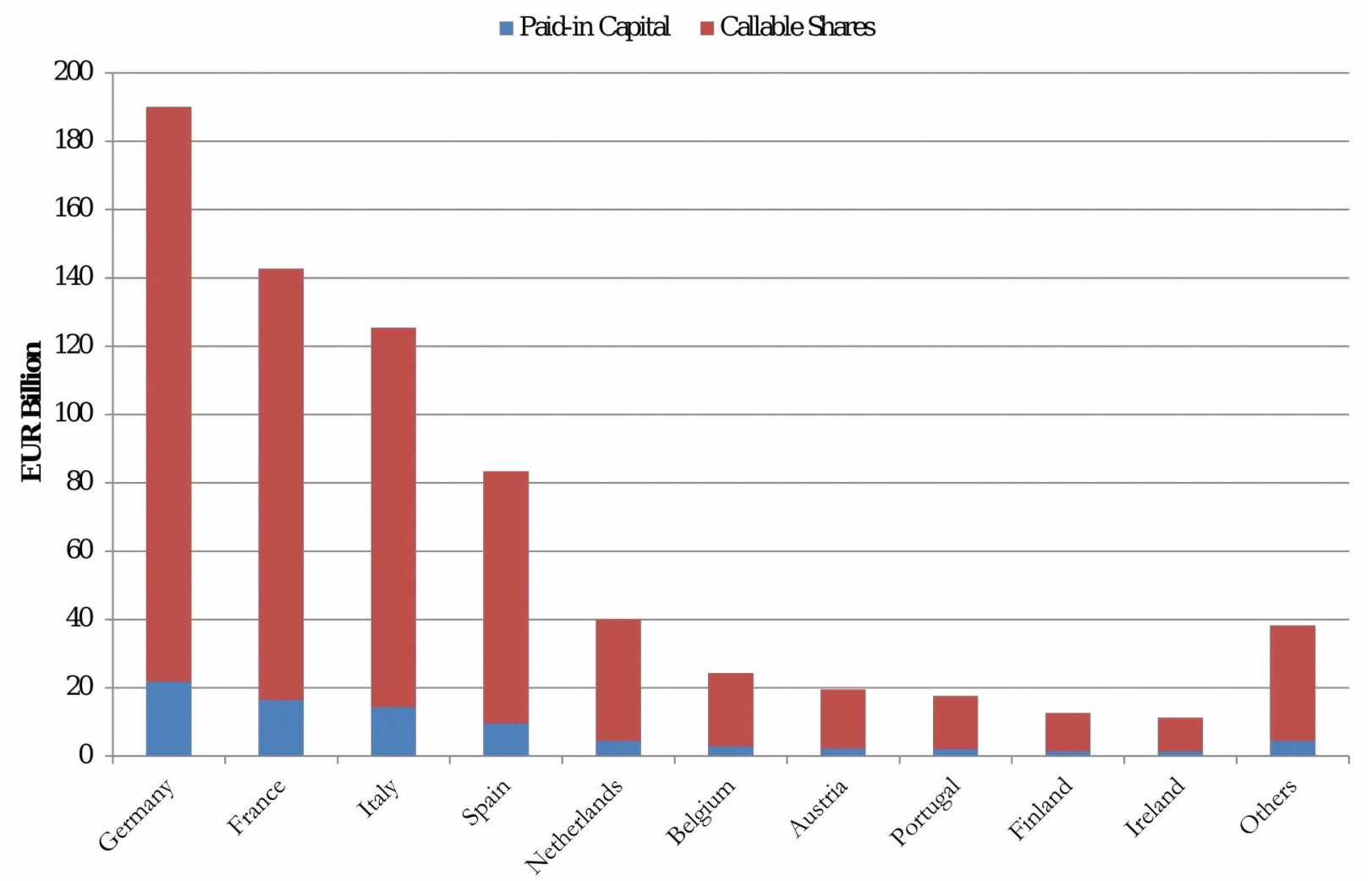

The ESM can raise funds by issuing investment-grade bonds and other liabilities. According to the Annual Report 2017, the Mechanism has issued debt securities for a total of €89.2 billion, an amount comparable to the paid-in capital. With this moderate leverage, the ESM has provided its financial assistance in the context of relatively small crises occurred in the Euro area: Greece and Cyprus received targeted loans at mitigated yields but conditioned upon the implementation of strict domestic reforms. The Mechanism was also involved in the indirect recapitalization of Spanish banks when they were going to end disrupted in 2012.

But in the event of a large shock hitting some major economy, the Mechanism could face a liquidity squeeze. Germany makes no secret that an ESM intervention in support of a big country such as Italy in front of a sovereign debt crisis would be far from obvious (German Council of Economic Experts, 2016).

The current machinery does not allow the ESM to concretely contribute to increase the resilience of the Eurozone. Rather, the Mechanism represents an additional cost, especially for those countries - such as Italy - which have been called for significant financial contributions at the time they were committed to fiscal consolidation programs and which remain exposed to the risk of a ESM failure to intervene in case of need. Put it differently: in return for its larger contribution to the ESM capital, Germany controls the decisions of the 
Mechanism through to the veto right; conversely Italy - which has already disbursed $€ 14.3 \mathrm{bn}$ - holds a veto right which is basically useless and has no guarantee of help in an adverse scenario.

More in general, today's ESM conformation is not in a position to foster stability to the extent that would be needed: it can only give a limited financial support of last resort, but does not play any preventive and/or counter-cyclical role that instead is indispensable to ensure long-term stability. And this is because the current governance structure of the EU delegates to the individual countries the implementation of domestic reforms in the misguided belief that the causes of problems are to be found exclusively in the fiscal profligacy of "rogue" countries, and not in the incompleteness and/or in the architectural flaws of the Monetary Union.

\section{Moving to a RISK-SHaRing Mechanism for Eurozone pUblic debt CONSISTENT WITH CAPITAL MARKET PRICES}

Classic Eurobond proposals (European Commission, 2011) were systematically opposed by core EU countries, which, to put it bluntly, perceived the mutualization of sovereign debts as a free-lunch to the periphery paid for by North European taxpayers.

The market-based risk-sharing mechanism presented in this paper excludes free lunches, is consistent with capital market constraints and makes moral hazard essentially vanishing. To this aim, the ESM should abandon the current loan-based approach in favor of an insurance-based structure in which the Stability Mechanism becomes the guarantor of the public debts and the countries which get a direct and immediate benefit from its guarantee pay an annual premium calculated at market prices.

The presence of the ESM guarantee would be ratified by new risk sharing clauses included in the Govies issued each year to refinance the maturing debt and would protect each member State against its own default risk provided that it fulfils some "well-behaving" conditions as described later on. It is important to stress that the ESM guarantee and the related mutualization of sovereign risks of Eurozone members do not mean a transfer of public debts from risky issuers to safe ones: each country would remain the only subject responsible for the payment duties owned to the holders of its government bonds.

The involvement of the Insurance Fund is only provided in conditions of high distress, and in any case only after the country concerned has tried to solve its financial problems by intervening on the debt still not guaranteed. Should this intervention be not sufficient, the country concerned could resort to the guarantee of the Stability Mechanism which will draw the funds needed from a 
suitable mix of equity and debt capital. Eventually, should this waterfall be still not enough, the ECB would be called upon to intervene, provided that specific conditions are satisfied; its support could be accepting bonds issued by the ESM as collateral in monetary policy operations and/or by including ESM securities in the context of its purchase intervention programs, including some form of OMTs (already conditioned upon the beneficiary country having received a financial support from the ESM) whose conditions would have to properly fit to the needs of the new Stability Mechanism.

It is worth observing that the waterfall just described includes some of the "well-behaving" conditions required to guaranteed countries: indeed, the risksharing clauses would provide for a seniority of government bonds covered by the guarantee with respect to those still uncovered. Thus, in case of default a member State would be required to hit first the portion of debt which does not include risk-sharing clauses; only in the event that such a move would not be enough to overcome its financial troubles, the Stability Mechanism would intervene with its financial resources and would be legitimized to increase its leverage in order to find the funds necessary to cover the losses, including the access to the ECB programs and collateral refinancing policies as above said.

Under the new set-up the securities assisted by risk-sharing clauses would become perfect substitutes and, therefore, would have the same return which would be representative of the riskiness of the Eurozone as a whole.

The ESM-guaranteed government bonds would represent a proper amount of Eurozone safe assets with respect to the needs of the financial system of the monetary union: at the end of the phase-in period, their outstanding notional amount would represent almost five times that of Bunds. This fact, obviously would contribute to the convergence of the Eurozone sovereign interest rate term structures to an only one, by removing the phenomenon of negative yields which still affects a wide region of the German term structure.

As it is known, the current ESM machinery foresees the progressive introduction in the government bonds of the Eurozone member of the so-called "model-CACs", that are collective action clauses which are aimed at making the management of the holdout problem easier in case of restructuring. Actually, these clauses also give a qualified minority of bond-holders the possibility to counter the conversion of payments associated to a given security into a new currency (other than the euro), hence hindering the willingness of a sovereign issuer to get a debt relief from redenomination into an eventual new (weaker) national currency by applying the principle known as Lex Monetae. However, CACs only represent a potential hurdle to redenomination: indeed, it is more reasonable to expect that a given State could dare a redenomination also of Local-Law bonds embedding CACs albeit incurring in some litigation risk. For this reason, several German influential economists (German Council of Economic Experts, 2016) suggested to replace model-CACs with Creditor 
Participation Clauses (CPCs), the latter explicitly forbidding debt redenomination.

But, a such provision could make sense only provided there is a common commitment of all the countries of the Euro bloc in favor of a wide-spread sustainability of the membership into the monetary union. Said differently: within a common currency area the prohibition of debt redenomination can coexist only with a full risk-sharing. Accordingly, our proposal for an upgrade of the ESM into a supranational umbrella for all EMU members meets German requests and provides for the said prohibition as a key feature of the risksharing clauses. The rationale is that if core countries accept a new set-up where sovereign risks are mutualized, it comes naturally that risky countries have to undertake a credible (and, thus, irreversible) commitment to the single currency and the related duties of belonging, also in fiscal terms.

In order to prevent moral hazard by risky countries - e.g. increasing their default risk by running a less prudent fiscal policy and therefore exploiting the less-risky ones - they would be required to make new cash contributions to the capital of the ESM equal to the difference between their sovereign risk and the Eurozone's average risk. As in a standard Credit Default Swap (CDS), the ESM (and, through it, low-risk countries) would sell protection to risky countries against their own excess-sovereign-risk and receive the annual premium for such insurance. At first glance, it might seem that the overall cost of debt for risky countries does not change with respect to the current situation since savings on interest expenditure for risk-shared debt would be offset by the cost of the guarantee paid to the Stability Mechanism. However, it should be emphasized that in the new set-up each country would pay an insurance premium which, ultimately, facilitates it to access a new equilibrium in which it will not have to pay extra-yields to the market compared to other sovereign issuers in the same currency area.

Also to prevent opportunistic conducts, we propose to set ex-ante limits on the maximum admissible increase of public debt compared to the initial stock and to provide very severe penalties in the event of exceeding these limits. In detail, each year the admissible nominal deficit for risky countries should not exceed the amount currently allowed by the Fiscal Compact plus the annual premium disbursed to the Stability Mechanism for the guarantee. As better described in the next sections, this latter component is a golden rule on investments: for each euro of premiums paid to the Insurance Fund risky countries would receive funds for new targeted investments by the Fund it-self which, as a financial vehicle, is allowed to use leverage and raise liquidity from standard bond-issuing activity in the financial market.

Breaching such covenants and restrictions - including provisions on admissible defaults on outstanding debt (first the uninsured and then the insured one) would result in the immediate loss of the supranational guarantee and the exit 
from the risk-sharing program with all consequences in terms of debt sustainability and membership in the monetary union. In addition during the transition period admissible defaults on the (insured) outstanding debt, triggering payments from the Insurance Fund to bondholders, would automatically result in new debt to the ESM matching the money paid out by the Fund. Once the transition period has expired, the ESM default would become a remote option: it could only occur after the attempt of the ESM to fund its unbalances through an increase of its leverage (i.e. by issuing bonds) and the eventual involvement of the ECB in order to keep under control the level of the Eurozone interest rates that at this stage would be represented by the cost of the debt.

Safest Eurozone countries - such as Germany or France - would not be required to increase their cash contributions to the ESM capital because they don't get an immediate and direct benefit from the guarantee and, as ESM shareholders, they have to bear a worsening of their credit standing and a consequent increase on the expenditure for interests on debt. Indeed, because of risksharing, they would be required to pay a higher coupon on the part of their public debt rolled over each year under the ESM guarantee. Approximately (except for carry over effects over time), the higher interest expenditure for safe countries is equal to the (positive) difference between the average sovereign credit risk of the Euro area and their country-specific credit risk. However the Insurance Fund design is flexible enough, as we shall see in the next sections of the paper, to allow for a level of ESM credit risk consistent with the best sovereign credit worthiness in so far as a sufficient level of equity capital were to be underwritten by Eurozone members to support the unexpected losses of the debt guarantee.

\section{Modelling Insurance fund and Government Budget Cash Flows}

The problem of an insufficient ESM backstop facility cannot be solved by the more prosperous nation taking on a blanket liability for paying back country $j$ 's bond because that will lead to reckless lending to $j$. However, it is possible to design joint, inter-government liability that can mitigate drastically this problem. Moreover, it is possible to design this in ways such that the more indebted nations as well as the countries taking on some of the Insurance Fund liability can both gain ${ }^{\circ}$. Credit insurance contracts and joint liability insurance schemes are well established institutions of our modern financial sector. Banks' deposit insurance scheme, such as the FDIC Agency run insurance program (Pennacchi, 2009) as well as the (soon to be launched) EDIS Fund in

\footnotetext{
TSee Basu and Stiglitz (2015) for an economic model showing how joint liability for sovereign debt can be Pareto superior to the status quo by entering into the appropriately designed insurance contract. Also, Tirole (2012) and Claessens et al. (2012) for an analysis of borrower solidarity in the Eurozone in the wake of the sovereign crisis.
} 
the Eurozone, the reinsurance market for catastrophic risk with pooling of risks taken up by insurance companies and issuance of CAT bonds, the large credit default swap market with several trillion worth of Corporates and Government names insured against default risk (BIS, 2016; Oehmke and Zawadowski, 2017), monoline US Insurance Companies guaranteeing Municipal Bonds holders against default and thereby allowing issuers to obtain a AAA rating. More broadly, US based Government Sponsored Enterprise (GSE) - such as Fannie and Freddie - and Agency (such as the FHA) guaranteeing trillion of bond issues against home mortgages default.

In this section we expose a simplified model for the cash-flows associated with our reform proposal of the ESM aiming at creating a Eurozone sovereigns' Insurance Fund. For the sake of streamlining the exposition we adopt the following simplifying assumptions:

1. The risk-less interest rate is constant over time;

2. The CDS-Bond basis is set at zero, namely there are no arbitrage opportunities across the CDS and Bond markets;

3. The speed of convergence towards the uniform level of CDS premium in the Eurozone is controlled by a given (increasing) function $y(t)$ of time, whereas the full version of the simulated model adopts a more complex path-dependent function which depends on the cumulated share of public debt insured by the Fund;

4. Under the reference scenario (no Insurance Fund) the sovereign credit risk of all countries remains constant over time;

5. For the purposes of calculating government spending, the extended version of our model includes the payment of insurance premiums not only on the annual increase in the shared debt but also on the stock data updated to the previous period. However, given the assumptions of convergence provided by the model, to make the exposition simple, we have reported here a version in which insurance premiums are paid exclusively on the annual flow of new debt guaranteed by the ESM.

The Insurance Fund implementation brings about a change in Government expenditure as a result of the following provisions:

- Insurance premia to be paid to the Insurance Fund (increasing expenditure for risky countries)

- Lower interest rates for the insured debt as a result of the ESM joint debt guarantee (reducing expenditure for risky countries)

- Gradual convergence of the interest rate on the uninsured debt towards the level of insured prevailing at the end of the transition period (reducing expenditure). 
We define the reference budgeted government spending flow related to public debt service without the ESM Insurance Fund as:

$$
G_{i}^{i} \equiv \rho_{i}^{i} D_{i}^{i}, i=1, N
$$

where $D_{i}^{i}$ is the total amount of public debt outstanding at the beginning of the transition period for each country $i$ ( $N$ denotes the number of countries), and $\rho_{i}^{i}$ the level of interest rates (cost of debt) prevailing without the ESM Insurance Fund. We decompose the level of interest rates in its two basic components:

$$
\rho_{i}^{i}=r+C D S_{i}^{i}, i=1, N
$$

where $C D S_{i}^{i}$ stands for the initial CDS premium quoted in the market and implied by the credit risk perceived by bondholders of sovereign (uninsured) debt for country $i$ and $r$ denotes the level of risk-less interest rate.

With the introduction of the Insurance Fund Government spending has to be adjusted as follows:

$$
G_{i}(t) \equiv \rho_{i}^{U} D_{i}^{U}(t)+\rho_{i}^{I}(t) D_{i}^{I}(t)+I P_{i}(t) d_{i}^{I}(t), i=1, N
$$

where the superscripts $U$ and $I$ refer to the uninsured and insured debt component respectively, $d_{i}^{I}(t)$ is the flow of debt which is rolled over and thereby insured and $I P_{i}(t)$ the amount of insurance premium - per euro of notional value, $d_{i}^{I}(t)$ - to be paid out to the Insurance Fund. Notice that the assumption that the flow of debt rolled over each year is fully risk shared implies that the cost of uninsured debt is constant over time and, precisely, the following equality holds:

$$
\rho_{i}^{U}=\rho_{i}^{i}, i=1, N
$$

Namely, uninsured debt cost stays the same as the cost of debt under the reference scenario of no Insurance Fund implementation.

By construction the uninsured debt component is equal to the total debt outstanding before the transition starts and declines as a result of its roll-over into the insurance scheme,

$$
D_{i}^{U}\left(t_{j}\right)=D_{i}^{U}\left(t_{j-1}\right)-d_{i}^{I}\left(t_{j}\right), \sum_{j=1}^{\tau} d_{i}^{I}\left(t_{j}\right)=D_{i}^{U}(0)=D_{i}^{i}, i=1, N ; j=1, \tau ; t_{\tau}=T,
$$

where $\left\{t_{j}\right\}$ is the set of maturity dates and $T$ is the end date of the transition.

The insurance premium is assumed to be proportional to the CDS premium with a minimum threshold,

$$
\max _{i} C D S_{i}(t)>C D S(t) \geq \min _{i} C D S_{i}(t) \geq 0
$$

below which no premium is paid, 


$$
\begin{gathered}
+i \geq 0 \\
\operatorname{CDS}_{i}(t)-C D S(t) \dot{i}_{i} \\
I P_{i}(t)=i
\end{gathered}
$$

where $\underset{i}{i} i_{i}$ stands for the positive part of the argument.

In our simulations the threshold level $C D S(t)$ is set to correspond to the observed average level of the CDS premium on (uninsured) sovereign debt. Of course, other assumptions can be adopted regarding the uniform level of credit risk, $C D S(t)$, that the Insurance Fund could guarantee to its members.

The level of insured debt changes over time as a result of the flow of new debt issued, $d_{i}^{I}\left(t_{j}\right)$, and the total amount of insurance premia, $d_{i}^{I}\left(t_{j}\right) I P_{i}\left(t_{j}\right)$, disbursed to the Fund

$$
D_{i}^{I}\left(t_{j}\right)=D_{i}^{I}\left(t_{j-1}\right)+d_{i}^{I}\left(t_{j}\right)\left[1+I P_{i}\left(t_{j}\right)\right], j=1, \tau ; i=1, N
$$

The model assumes that the level of interest rate for all insured debt is given by

$$
\rho_{i}^{I}(t)=r+C \dot{S} S(t), i=1, N
$$

Hence, the implied credit risk premium for the insured debt would be equalized across countries to level $C D S(t)$, as a result of the (uniform) value of the ESM guarantee. Therefore the value of the threshold, $C D S(t)$, can be thought of as the level of the CDS premium written on the ESM credit name. However it is clear that countries with a lower CDS premium level than $C D S(t)$ would suffer an increase in their cost of debt.

We close the model with the specification of the CDS premium quoted in the market for any given country $i$ at any given time $t>0$,

$$
\begin{gathered}
C D S_{i}(t)=(1-\gamma(t)) C D S_{i}(t-1)+\gamma(t) C D S(t-1), \\
\gamma(t) \in[0,1], \gamma(0)=0, \gamma(T)=1, \gamma^{\prime}(t) \geq 0
\end{gathered}
$$

with $C D S_{i}(0)=C D S_{i}^{i}$ and where $y(t)$ is a given increasing function of time regulating the speed of convergence towards the uniform level of CDS premium in the Eurozone. In essence, the CDS premium on uninsured debt converges gradually over the transition period to the same level as the insured debt. Of course, the uninsured debt component is gradually replaced over the transition period by the issuance of insured debt and it will be fully substituted at time $T$. For the sake of simplicity we assume that the speed of converge, $y(t)$, is uniform across countries. 
We now take the difference between (3) and (1) to get the impact on the government budget expenditure as a result of participating into the Insurance Fund,

$$
G_{i}(t)-G_{i}^{i}=\rho_{i}^{U} D_{i}^{U}(t)+\rho_{i}^{I}(t) D_{i}^{I}(t)+I P_{i}(t) d_{i}^{I}(t)-\rho_{i}^{i} D_{i}^{i}, t=[0, T]
$$

Adding and subtracting $\rho_{i}^{i} D_{i}^{I}$ from the right-hand-side of (11), substituting (4) and rearranging the terms we get

$$
G_{i}(t)-G_{i}^{i}=\rho_{i}^{i}\left[D_{i}(t)-D_{i}^{i}\right]+\left[\rho_{i}^{I}(t)-\rho_{i}^{i}\right] D_{i}^{I}(t)+I P_{i}(t) d_{i}^{I}(t), t=[0, T]
$$

wit

$\mathrm{h}$

$$
D_{i}(t) \equiv D_{i}^{I}(t)+D_{i}^{U}(t), D_{i}(0)=D_{i}^{i}
$$

denoting total outstanding debt, insured as well as uninsured.

Substituting (2), (5), (7) and (9) into (12), we get the following expression

$$
\begin{aligned}
G_{i}(t)-G_{i}^{i}=\left[r+C D S_{i}^{i}\right][ & \left.D_{i}(t)-D_{i}(0)\right]+\left[C D S(t)-C D S_{i}^{i}\right] D_{i}^{I}(t)+i \\
& (t) \\
& C D S_{i}(t)-C D S i \\
& +i d_{i}^{I}(t), t=[0, T]
\end{aligned}
$$

Then, substituting (10) into (14) we have a measure of the Insurance Fund impact on the Government budget spending during the transition period,

which depends on

$$
\begin{gathered}
G_{i}(t)-G_{i}^{i}=\left[r+C D S_{i}^{i}\right]\left[D_{i}(t)-D_{i}(0)\right]+\left(C D S(t)-C D S_{i}^{i}\right) D_{i}^{I}(t)+i \\
(t) \\
(1-\gamma(t)) C D S_{i}(t-1)+\gamma(t) C D S(t-1)-C D S i \\
\dot{i} \\
+i d_{i}^{I}(t) \\
+i \\
t=[0, T]
\end{gathered}
$$

1) the level of credit risk measures and risk-less rate, e.g. $C D S_{i}^{b}, C D S(t)$ and $r$;

2) the change in total debt, $\left[D_{i}(t)-D_{i}(0)\right]$;

3) the level of insured debt, $D_{i}^{I}(t)$;

4) the speed of credit risk convergence, $y(t)$, to the uniform level implied by the insurance guarantee;

Notice that the change in total debt level during the transition period is constrained by the amount of insurance premia paid into the Fund pool and therefore we have, 


$$
D_{i}(t)=D_{i}(0)+\sum_{\tau=0}^{\tau=t} d_{i}^{I}(\tau) I P_{i}(\tau) i=1, N
$$

When the transition is completed, all outstanding debt would be insured debt and there is no more insurance to be purchased:

$$
D_{i}^{I}(t)=D_{i}(t), d_{i}^{I}(t)=0, t>T
$$

As a result, substituting (17) into (15) the latter would be simplified as follows,

$$
\begin{gathered}
G_{i}(t)-G_{i}^{i}=\left[r+C D S_{i}^{i}\right]\left[D_{i}(t)-D_{i}(0)\right]+\left(C D S(t)-C D S_{i}^{i}\right) D_{i}(t)=i \\
i[r+C D S(t)] D_{i}(t)-\left[r+C D S_{i}^{i}\right] D_{i}(0), \quad t>T
\end{gathered}
$$

If total debt has not changed much over the transition period,

$$
D_{i}(t) \cong D_{i}(0), t \in[0, T]
$$

equation (18) can then be reasonably approximated by the following expression,

$$
G_{i}(t)-G_{i}^{i} \cong\left[C \dot{D} S(t)-C D S_{i}^{i}\right] D_{i}(0), t>T
$$

Thus, the (steady state) change in credit risk spread over the transition period becomes the determinant of budgetary savings (or costs) induced by the insurance scheme operations. A shrinking spread entails lower budget spending as a result of interest rate decline and vice versa.

It is also interesting to investigate the budget implications during the transition for sovereign debt with lower credit risk - which would entail no insurance premium to be paid - and relatively stable debt, such as north European countries (e.g. Germany). In this case we can find a good approximation of (15) can be obtained by assuming

$$
D_{i}(t) \cong D_{i}(0), I P_{i}(t)=0, t \in[0, T]
$$

which yields,

$$
G_{i}(t)-G_{i}^{i} \cong\left(C D S(t)-C D S_{i}^{i}\right) D_{i}^{I}(t), t \in[0, T]
$$

For the lowest sovereign credit spread it is very likely that (22) would be positive - e.g. budget spending would increase as a result of participating into the insurance scheme - because it should normally be expected that the riskshared Eurozone credit spread staying above the best credit levels,

$$
C D S(t)>C D S_{i}^{i}
$$

That said, however, nothing (in principle) would prevent the ESM to be sufficiently well capitalized to target a lower level of risk - e.g. ruin probability 
of the Insurance Fund - which could be very close to that of the best sovereign credit names in the Eurozone,

$$
C D S(t) \cong \min _{i} C D S_{i}^{i}
$$

Let us consider the case where (24) holds and imagine that, for the sake of exposition, Germany (denoted with subscript $D E$ ) being the best credit name in the pool permanently,

$$
C D S(t)=C D S_{D E}(t)=\arg \min _{i} C D S_{i}^{i}
$$

No insurance premium would therefore be charged,

$$
\begin{gathered}
(t) \\
C D S_{D E}(t)-C D S i \\
i \quad i=0 \\
i
\end{gathered}
$$

We know from (16) that total debt would stay constant over the transition if insurance premia are not disbursed, therefor it turns out that

$$
D_{D E}(t)-D_{D E}(0)=0
$$

Substituting (26) and (27) into (14) we get the change of Government spending for Germany as

$$
G_{D E}(t)-G_{D E}^{i}=\left[C D S(t)-C D S_{D E}^{i}\right] D_{D E}^{I}(t)=0, t \in[0, T]
$$

Because being Germany assumed to be the best credit at the inception of the transition, namely

$$
C D S_{D E}^{i} \equiv \arg \min _{i} C D S_{i}^{i}
$$

replacing (26) and (29) into (28) the term in the square bracket is zero. Same expression (28) applies if we consider budget spending after the transition is completed as in (18).

Thus, we can conclude that participating into the Insurance Fund would not cost a penny to the German fiscal budget if the targeted credit risk of the Fund matches the best credit name.

We now turn to the question what would happen to a sovereign budget of a weaker credit name, say Italy (subscript, IT), in the same scenario. To simplify the exposition it is convenient to assume that the targeted credit risk is, realistically, sufficiently close to zero (say just few basis points),

$$
C D S(t) \cong 0
$$


We can use (30) to simplify insurance premium payment (7) as

$$
\begin{gathered}
(t) \\
C D S_{I T}(t)-C D S i \\
\dot{i} \\
+i \cong C D S_{I T}(t) \\
I P_{I T}(t) \equiv \dot{i}
\end{gathered}
$$

We can substitute (30) and (31) into (14) and use (16) to get the budget spending change for Italy,

$$
\begin{aligned}
G_{I T}(t)-G_{I T}^{i} \cong[r+ & \left.C D S_{I T}^{i}\right] \sum_{\tau=0}^{\tau=t} C D S_{I T}(\tau) d_{i}^{I}(\tau)-C D S_{I T}^{i} D_{I T}^{I}(t)+i \\
& +C D S_{I T}(t) d_{I T}^{I}(t), t=[0, T]
\end{aligned}
$$

Notice that the first term of the right-hand side of (32), which is positive, turns out to be small since one of the terms of the product, namely

$$
\left[r+C D S_{I T}^{i}\right] C D S_{I T}(t) \cong 0, t \in[0, T]
$$

could be estimated at around 3 to 4 basis points. Thus we are left with the expression (32)

$$
G_{I T}(t)-G_{I T}^{i} \cong-C D S_{I T}^{i} D_{I T}^{I}(t)+C D S_{I T}(t) d_{I T}^{I}(t)<0, t=[0, T]
$$

which is negative, since it must be the case that in light of (16) we have,

$$
D_{I T}^{I}(t)>d_{I T}^{I}(t), t=i
$$

while (10), coupled with the constraint that Italy's CDS starts at higher level than the Eurozone target credit spread,

$$
C D S_{I T}^{i}>C D S(t) \cong 0
$$

it implies that,

$$
C D S_{I T}^{i}>C D S_{I T}(t), t=i
$$

As the transition ends, insurance purchases stop (see, 17) and therefore budget spending (34) change declines further to

$$
G_{I T}(t)-G_{I T}^{i} \cong-C^{2} S_{I T}^{i} D_{I T}^{I}(t)=-C D S_{I T}^{i} D_{I T}(t)<0, t>T
$$

which would correspond to the full impact of the convergence towards (near) zero of Italy's CDS spread - as assumed in (30) - reducing interest payments to bondholders accordingly. 


\section{Simulating Insurance Fund and Government Budget Cash Flows}

Table 1 shows the estimated annual evolution of the differential interest expenditure on the debt borne by the various countries assuming the proposed reform is implemented ${ }^{\circ}$. For risky countries such as Italy, Spain and Portugal, the data in the table also take into account the premiums to be paid annually to the Stability Mechanism:

\section{Table 1 - $\quad$ Estimated impact of the ESM reform on the interest expenditure, net of the premium paid for the guarantee on debt shared (EUR billion)}

\begin{tabular}{|l|c|c|c|c|c|c|c|c|c|c|c|}
\hline Country & year $\mathbf{1}$ & year $\mathbf{2}$ & year $\mathbf{3}$ & year $\mathbf{4}$ & year $\mathbf{5}$ & year $\mathbf{6}$ & year $\mathbf{7}$ & year $\mathbf{8}$ & year $\mathbf{9}$ & year $\mathbf{1 0}$ & Total \\
\hline Germany & 1.8 & 3.2 & 4.2 & 5.0 & 5.7 & 6.3 & 6.9 & 7.4 & 7.9 & 8.3 & $\mathbf{5 6 . 8}$ \\
\hline France & 1.0 & 1.7 & 2.1 & 2.3 & 2.3 & 2.1 & 1.9 & 1.5 & 1.0 & 0.4 & $\mathbf{1 6 . 3}$ \\
\hline Italy & 0.5 & -0.1 & -1.6 & -4.0 & -7.2 & -10.8 & -14.7 & -18.8 & -23.1 & -27.7 & $\mathbf{- 1 0 7 . 4}$ \\
\hline Spain & -0.4 & -1.1 & -2.1 & -3.5 & -5.0 & -6.7 & -8.5 & -10.4 & -12.4 & -14.5 & $-\mathbf{- 6 4 . 4}$ \\
\hline Portugal & 0.0 & -0.2 & -0.5 & -1.0 & -1.5 & -2.1 & -2.7 & -3.3 & -4.0 & -4.7 & $\mathbf{- 2 0}$ \\
\hline Austria & 0.2 & 0.3 & 0.3 & 0.4 & 0.3 & 0.3 & 0.3 & 0.2 & 0.2 & 0.1 & $\mathbf{2 . 7}$ \\
\hline Netherlands & 0.3 & 0.5 & 0.7 & 0.8 & 1.0 & 1.1 & 1.2 & 1.3 & 1.3 & 1.4 & $\mathbf{9 . 6}$ \\
\hline Belgium & 0.2 & 0.3 & 0.3 & 0.2 & 0.1 & 0.0 & -0.1 & -0.3 & -0.4 & -0.6 & $-\mathbf{- 0 . 2}$ \\
\hline Finland & 0.1 & 0.2 & 0.3 & 0.4 & 0.4 & 0.5 & 0.5 & 0.5 & 0.5 & 0.5 & $\mathbf{3 . 9}$ \\
\hline Ireland & 0.1 & 0.1 & 0.1 & 0.1 & 0.0 & -0.1 & -0.1 & -0.2 & -0.2 & -0.3 & $\mathbf{- 0 . 5}$ \\
\hline
\end{tabular}

The above table suggests different considerations. First, the benefit from the reform for risky countries is increasing over time. The phenomenon can be grasped at a glance for Italy, Spain and Portugal, and - at a closer look - also for countries with an intermediate level of risk such as Belgium and Ireland.

The case of Italy is particularly interesting: in the first year the saving of interests on the debt is lower than the premium to be paid to the ESM but already from the second year the situation is reversed and the country begins

TInput data as of September 2017.

TEstimates exhibited in Table 1 refer to average data, also because the term structure of sovereign bonds includes securities whose residual maturity is longer than 10 years. 
to get a net benefit because of the reduction in the annual premium to be disbursed (Figure 3 ).

\section{Figure 3 - Costs and benefits of the ESM reform for Italy ${ }^{\circ}$}

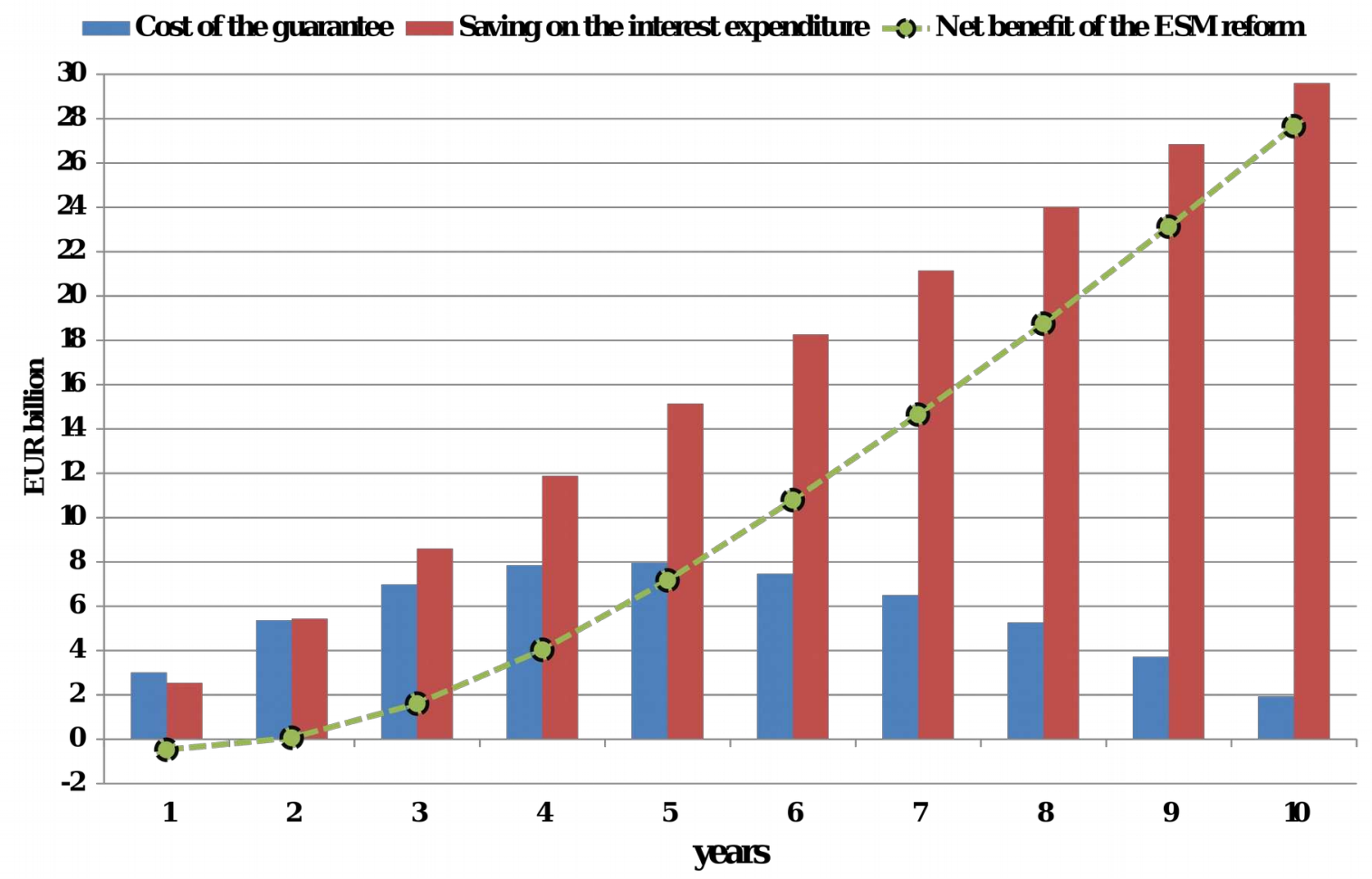

This premium depends on two conflicting forces: the increasing amount of guaranteed debt and the reduction of the percentage premium produced by the progressive convergence between the various countries. Initially, the first component prevails but then it is more than offset by the second.

At this point it is useful to delve into the dynamics that would lead to the convergence between the yield curves of the different Eurozone members and, therefore, to the zeroing of the sovereign spreads. These dynamics are connected to the revision of the expectations of the market agents who, in view of the commitment of all countries to share their sovereign risks, over time update their risk attitude in favor of countries with large debt-to-GDP ratios. We expect that the agreement on the ESM guarantee paid at market price would trigger large convergence trades, that is global macro strategies played by hedge funds and other institutional investors which - expecting the alignment of the credit risk across Eurozone members produced by risk sharing - would try to make profits from the anticipation of such market movements by selling expensive low-yield Govies (such as German bonds) and buying cheap highyield Govies (such as Italian bonds).

The same phenomenon occurred between the end of the 1990s and the early 2000s, when the widespread perception that the risks of the Euro countries

TInput data as of September 2017. 
were shared pushed several global macro funds to participate in the convergence phenomenon and allowed them to pocket significant gains (Curto, Nunes and Oliveira, 2012, Lhabitant, 2015).

Similar dynamics explain why until 2007 there was no clear relationship between the debt-to-GDP ratio of the various Eurozone countries and long-term yields on government bonds (Figure 4 ).

The onset of the global crisis and the strategy of risk segregation applied by core countries have subverted markets' sentiment, fueling divergence trades on Eurozone Govies (e.g. sell BTP to buy Bund).

Figure 4 -Long-term yields on Eurozone Govies today better reflect differences in government debt than prior the crisis

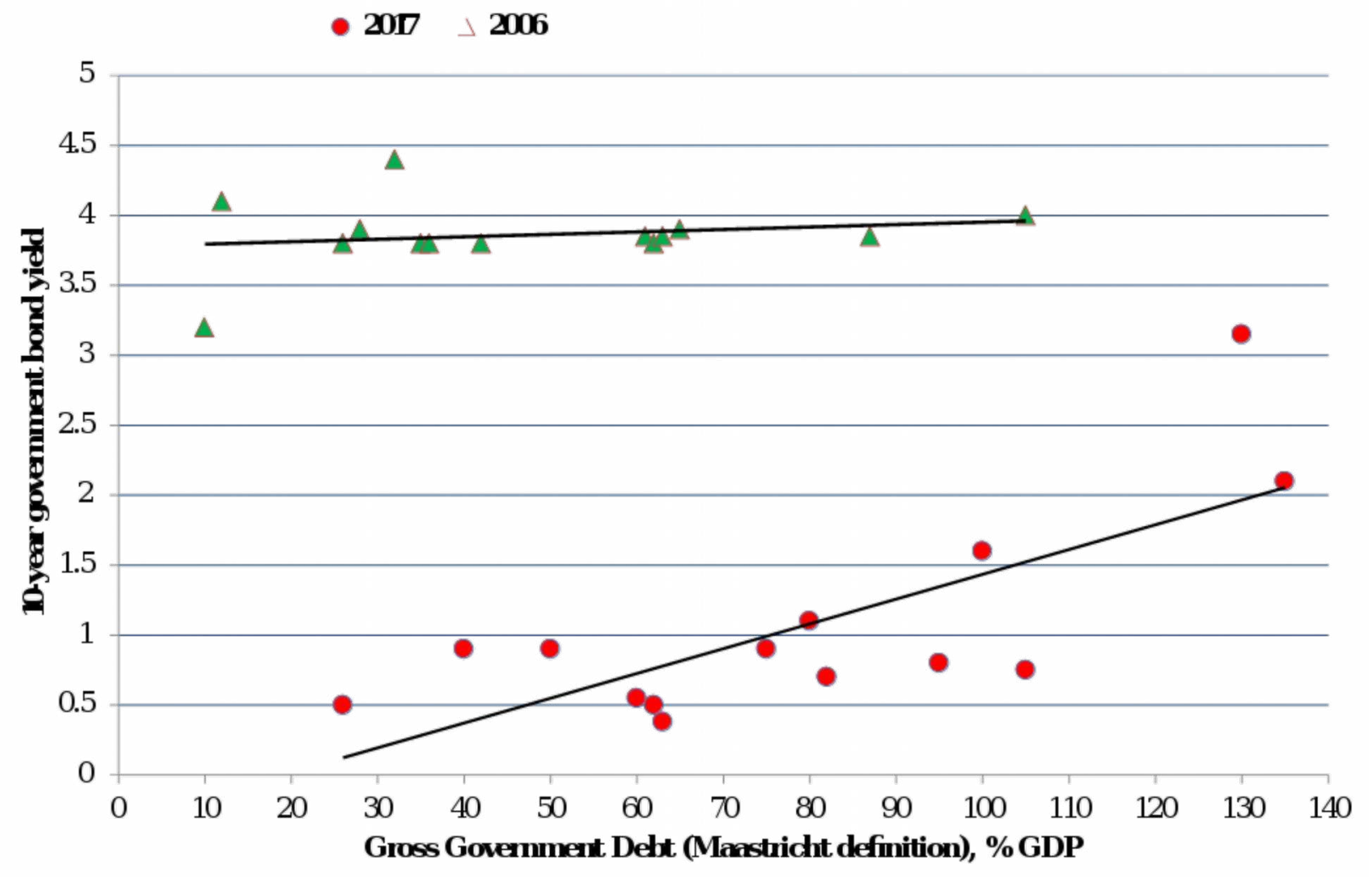

Note only OECD EU-areamember oountries, excluding Greoe

Source: OECD

Coming back to the proposal of this work, we can reasonably expect that even if, at first, markets should exhibit some inertia in updating their expectations - the worsening of the risk perception would be bounded to outstanding Govies because they do not embed risk sharing provisions and are subordinated to bonds covered by the ESM guarantee. However, such uncomfortable scenario (which would fade away in front of the gradual increase in the incidence of public debt with risk-sharing clauses) should not be too critical. Most of the public debt of Eurozone countries pays fixed coupons, 
meaning that its cost for the public budget would be almost insensitive to an increase of the implied yields; whereas, from the standpoint of bondholders, these Govies would become an investment to hold up to maturity in order to avoid any capital losses. Moreover, hopefully the implementation of the proposal here illustrated should improve markets' attitude about the resilience of the Euro area and, consequently, reduce the perception of the risk of a Euro break-up (in terms of default probabilities and, consequently, of expected losses) that would benefit also the yields on Govies not covered by the guarantee, partially offsetting the premium associated with subordination clauses on such bonds.

Obviously any additional provision intended to strengthen markets' confidence in the risk sharing commitment of the Euro countries would speed up the convergence of their yield curves. In this perspective, the ECB monetary financing prohibition written in its Statute would become less of constraint. After all, the mutualization of sovereign risks achieved through risk-sharing clauses would make virtually redundant such prohibition.

The described convergent dynamics would also gradually reduce the additional burden of the proposed ESM reform for low-risk countries, although only as second order effect. In fact, the larger and larger amount of public debt enclosing risk-sharing clauses would necessarily increase year by year the additional interest expenditure of these countries; however, thanks to the convergence of the yield curves, the marginal increase would be descending over time (Figure 5).

\section{Figure 5 -Second order effect of the ESM reform on the interest expenditure of Germany and France}




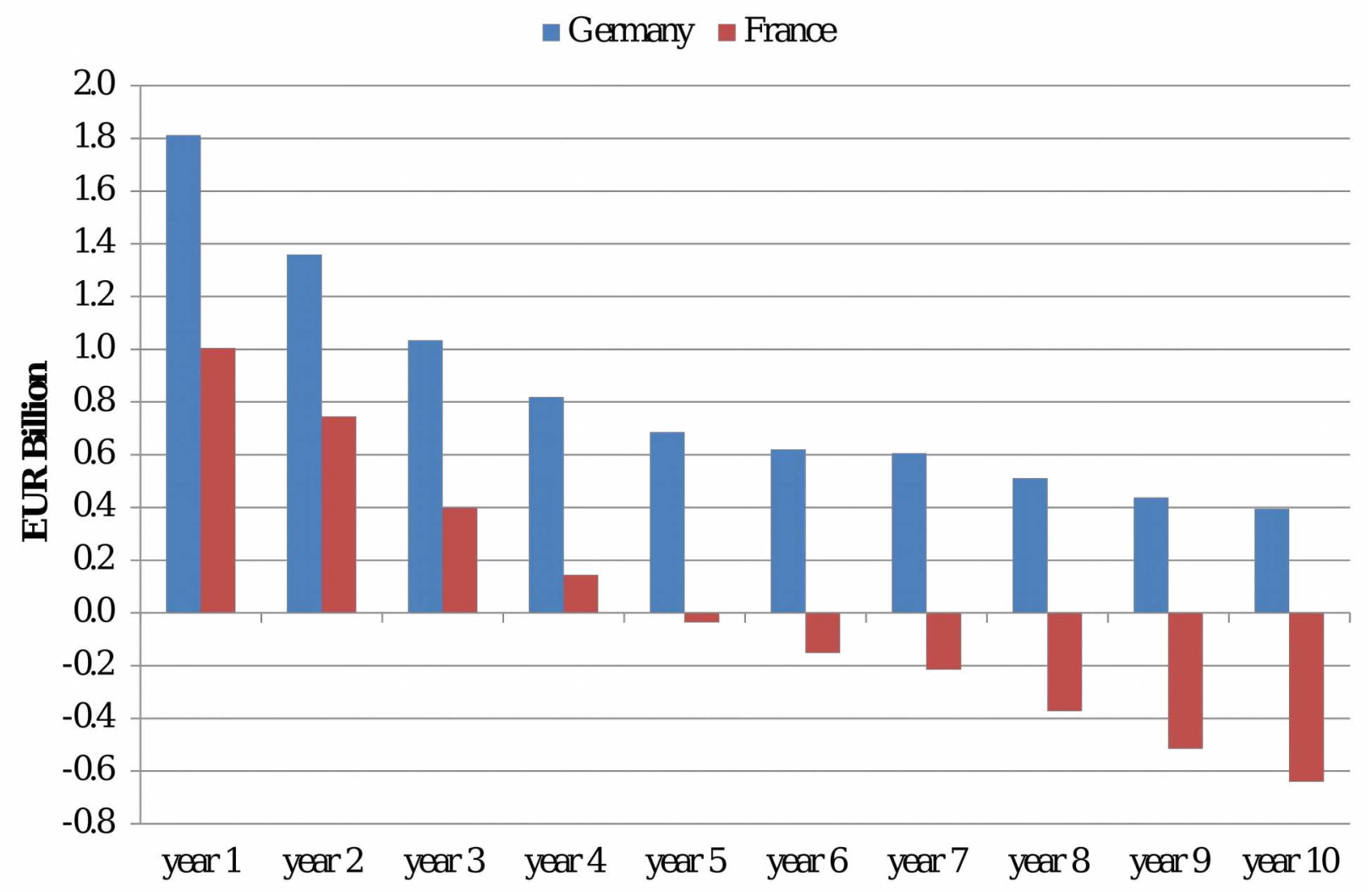

It remains understood that data in Table 1 confirm the foreseeable redistributive impact of the reform. Countries like Germany and France would have to bear a higher debt cost of $€ 56.8$ billion of $€ 6.3$ billion respectively in cumulative terms over 10 years, while risky countries would realize significant cost savings: - $€ 107.4$ billion Italy, - $€ 64.4$ billion Spain and so on.

It would be a complete reversal with respect to the direction followed by intraEurozone flows of financial resources since the eruption of the crisis. In fact, systematic risk segregation has allowed core countries - Germany first and foremost - to attract resources from the periphery as happened, for example, in the redistribution of ECB profits from the Securities Markets Programme or in the Quantitative Easing where the capital key criterion has enabled Germany to make large profits from the refinancing of its public debt. To have an idea of this "magnet-effect" one should consider that from 2008 to 2016 the interest expenditure on the Italian public debt was $€ 150$ billion over that of Germany although the sizes of the two debts are comparable in absolute terms (Bundesbank, 2017).

Nor we should underestimate the implications of the greater stability assured to the Eurozone by the new structure of the ESM. The presence of a supranational guarantor such as the sovereign bailout fund, the homogenization and, subsequently, the convergence of the interest rates of the various member countries towards common values would increase the resilience of the 
Eurozone going to reduce the tail risk, meant as the risk of an emergency involvement of the Stability Mechanism in the bailout of a State. Conversely, under the old structure, each country remains subject to the risk of having to shell out additional contributions to the ESM capital if it had been asked to monetize its callable shares.

Table 2 compares, for each country, the contingent liability represented by the quota of callable shares of the current ESM with the cumulative net cost/benefit under the new structure based on risk sharing. The estimated savings would exceed $€ 100$ billion for each of the 4 larger countries.

TBenefits are displayed with the minus sign. 
Table 2 - Estimated savings associated with the shift from the current ESM capital structure to the new regime with risk (EUR billion) sharing

\begin{tabular}{|l|c|c|c|}
\hline Country & $\begin{array}{c}\text { Contingent liability } \\
\text { fromcallable sheres }\end{array}$ & $\begin{array}{c}\text { Net cost (benefit) under } \\
\text { the naw ESM }\end{array}$ & $\begin{array}{r}\text { E: } \\
\text { shi }\end{array}$ \\
\hline Germany & 168.3 & $\mathbf{5 6 . 8}$ \\
\hline France & 126.4 & $\mathbf{1 6 . 3}$ \\
\hline Italy & 111.1 & $\mathbf{- 1 0 7 . 4}$ \\
\hline Spain & 73.8 & $\mathbf{- 6 4 . 4}$ \\
\hline Portugal & 15.6 & $\mathbf{- 2 0}$ \\
\hline Austria & 17.3 & $\mathbf{2 . 7}$ \\
\hline Netherlands & 35.6 & $\mathbf{9 . 6}$ \\
\hline
\end{tabular}

The proposed overhauling of the Stability Mechanism would also fix the liquidity risk which is currently embedded in its capital structure. The entire ESM capital would become immediately available because the annual premiums charged to risky countries would be paid cash: by the end of the tenth year, the paid capital of the Stability Mechanism would reach a total amount of about $€ 200$ billion. It would mean more than 2 times the most solid form of financial backing available to the ESM with respect to today's framework in which the Mechanism can rely on slightly more than €80 billion cash, the remaining $€ 625$ billion being a contingent claim.

The transition to an insurance-based contributory mechanism should necessarily be paired with a revision of the ESM governance according to a more democratic perspective, with the removal of the current provision that preserves the veto right of the 3 larger shareholders also under the emergency voting procedure. The loss of such right would matter mainly for Germany which so far has threatened its veto any time it was unsatisfied with the conditions of the aid programs to distressed countries. Hopefully, the larger stability granted by the new set-up should make the Eurozone crisis-proof and consequently reduce the likelihood of needing new financial assistance programs within Euro members, making the loss of supremacy more acceptable to Germany. 
Moreover, as already argued, the issuance of ESM bonds over the entire interest rate term structure would eventually contribute to the creation of an authentic Eurozone safe-asset which should be a corner stone for any stable currency area. This would eliminate the distortion that sees the Bund playing this role with the anomalous implications of generating negative yields - as a result of a spurious scarcity effect - that hare hurting balance-sheets of banks, insurance companies and pension/mutual funds. These new ESM bonds in fact will accompany the guaranteed Eurozone Govies in the role of safe collateral within the financial markets by strengthening, as a result, the Capital Markets Union.

Indeed, the ultimate aim of the reform is to share risks in order to significantly increase the overall distance to default of all members of the Euro bloc and make the ESM an authentic stability guarantor (free from the constraint of preventive approval by certain member states political institutions).

We estimate that the shift to the risk-sharing clauses would deliver a generalized reduction of the debt-to-GDP ratios and a consequent improvement of the debt sustainability for any State. On average, even most indebted countries such as Italy and Portugal would reach a ratio below $100 \%$ at the end of the $10^{\text {th }}$ year, while the ratio would approach the Maastricht threshold of $60 \%$ (Figure 6).

\section{Figure 6 -Estimated path of the debt-to-GDP ratio over the 10- year convergence period ${ }^{\circ}$}

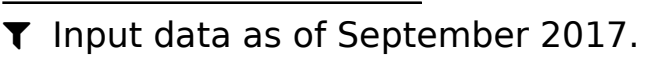




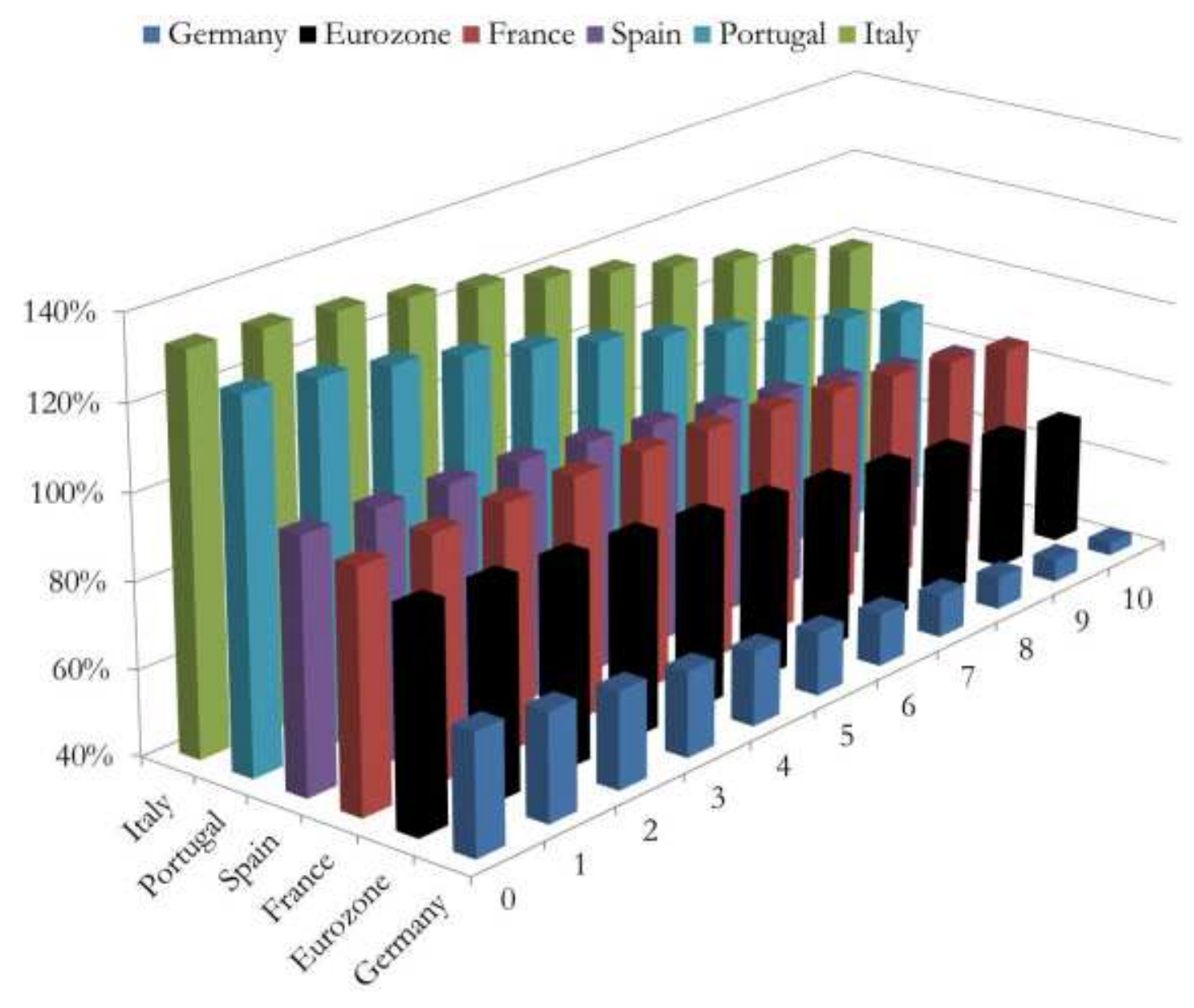

It remains understood that we refer to average values: depending on the residual time to maturity of government bonds, it may well happen that after 10 years we are still left with a residual of bonds still not under the ESM umbrella and, therefore, it may be the case that yield curves of Eurozone Govies aren't yet fully overlapped. If this was the case, it's clear that countries with an excess-sovereign risk with respect to the average of the Euro area would have to continue to pay (albeit low) annual premiums to the ESM until the completed overlapping would be achieved.

We want to stress that, in any case, Figure 6 reports only a theoretical situation because over time an increasing part of the debt of each country falls under risk-sharing provisions. A graphical representation of such dynamics is provided in Figure 7. 
Figure 7 -Estimated time evolution of risk-shared and not risk shared public debt

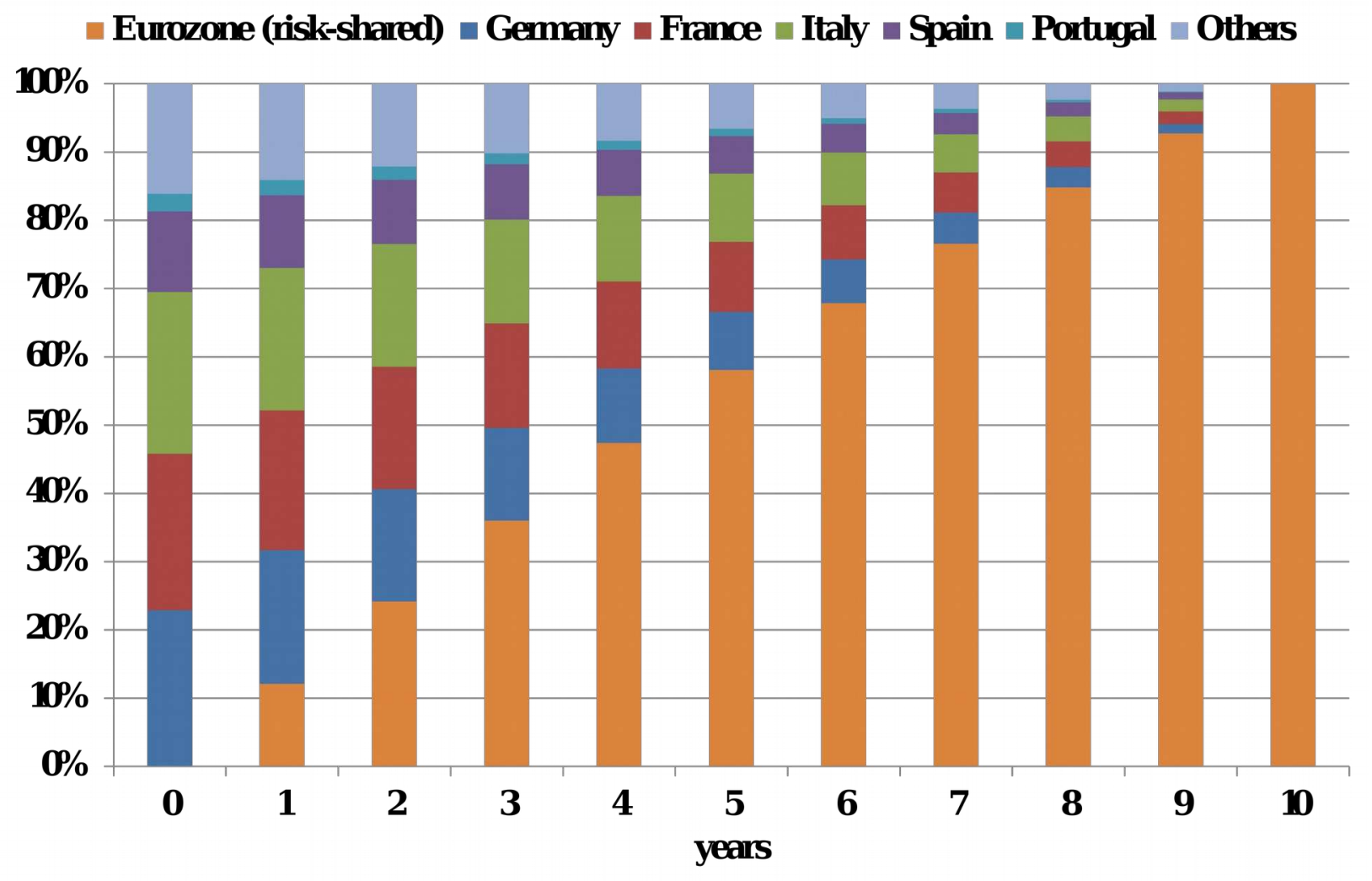

Given the scheme of incentives and penalties associated with the proposed reform, we reasonably expect a progressive synchronization of key financial and economic magnitudes across members countries, such as the primary balance, the average coupon paid on government bonds and the spread on sovereign CDS contracts. Figures 8 to $10^{\circ}$-report the expected patterns of these magnitudes for selected Eurozone countries up to 10 years since inception of the revised Stability Mechanism.

Figure 8 -Estimated time evolution of the primary balance for selected Eurozone countries

TInput data as of September 2017. 


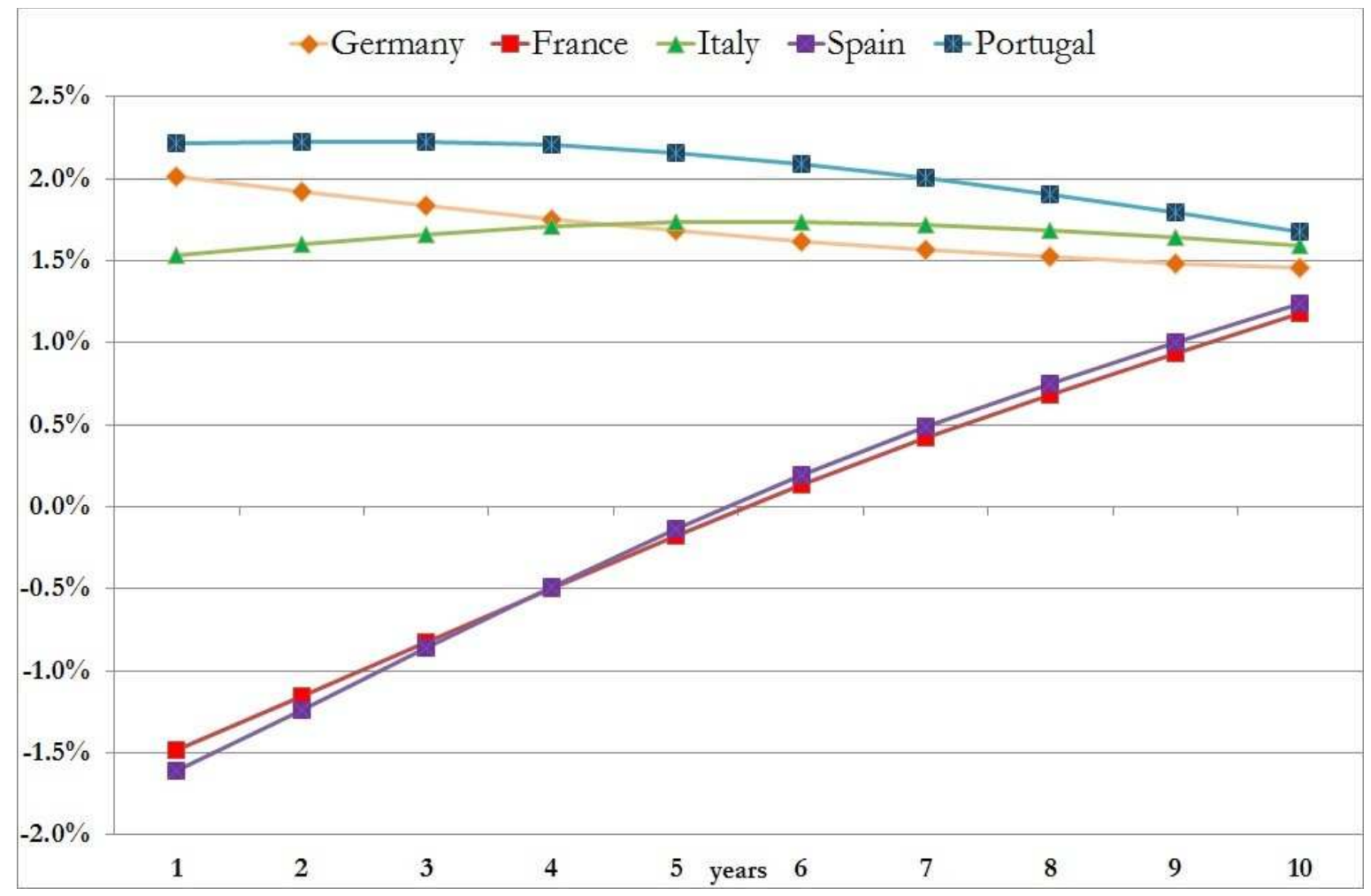

Figure 9 -Estimated time evolution of the average coupon on public debt for selected Eurozone countries 


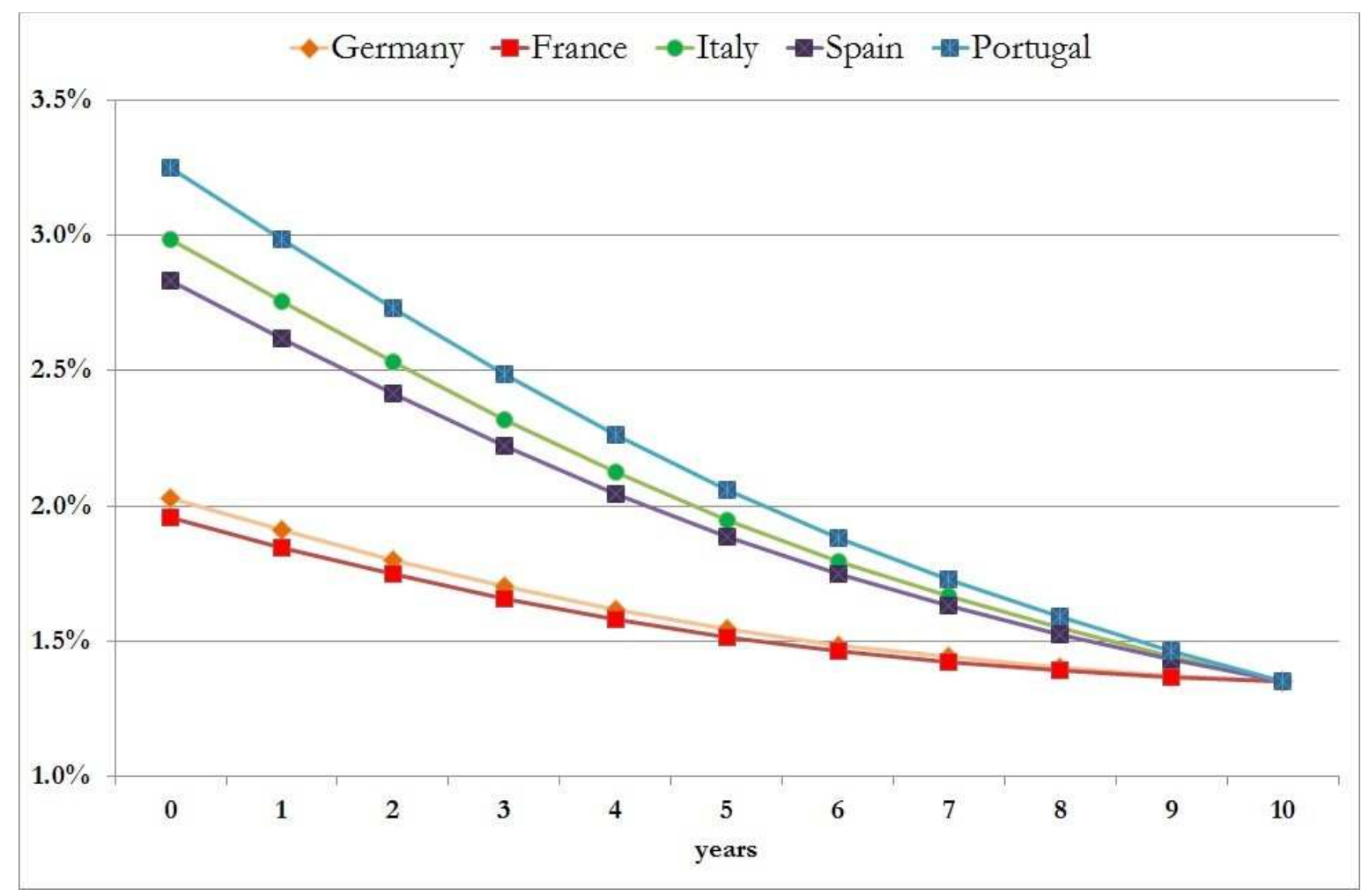

Figure 10 - Estimated time evolution of the sovereign CDS spreads for selected Eurozone countries

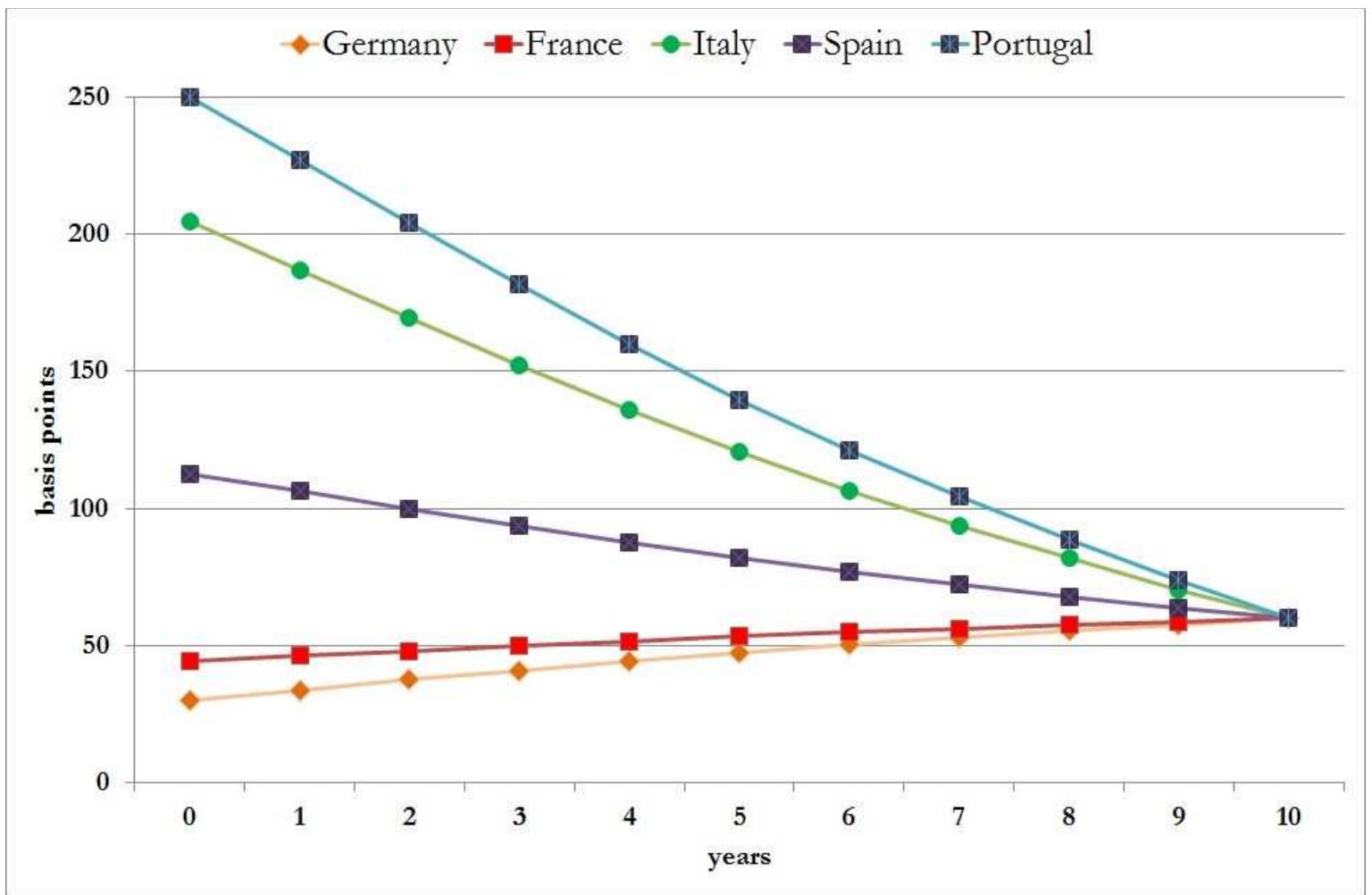

During the transition period the Stability Mechanism could use its leverage capability to issue investment-grade liabilities appropriately distributed along 
the key maturities of the term structure. Along with Govies embedding risksharing clauses, these supranational bonds would make available - at least in an embryonic version - an authentic Eurozone safe to the capital markets. This would make it possible to correct one of the main anomalies of the European Monetary Union, namely the fact that, since the eruption of the global financial crisis, the role of Eurozone safe asset has been improperly played by German Bunds with all the unintended consequences related to the scarcity of the latter. This role - albeit reflecting a matter of fact (i.e. the outstanding credit worthiness of Germany with respect to its partners) - stems from the combination of the Eurozone architectural fragilities with the risk segregation strategy that Germany and other cores countries have carried on at least since the beginning of this decade.

The convergence targets that the proposed reform aims to achieve would create a robust ground for the following shift to a federal debt of the Euro area. Once completed the phasing-in period, time would be ripe for the next step: a single federal debt of the Euro area as a whole. Indeed, the reconciliation of the roles of public debt guarantor and project financer within the same supranational institution would lead to the natural transition to a single Eurozone's Finance Minister appointed for the management of a federal budget and a federal debt and entitled to rely on a cooperative monetary policy by the European Central Bank. As for the federal budget, obviously it would also entail the provision for federal revenues, for instance in the form of a proportional share of the tax income of each member country; whereas, with regard to the federal debt, we envisaged the gradual shift of the ESM from the role of covenant-provider to that of direct issuer of supranational bonds of the Euro area as a whole (Eurobonds).

The benefits associated with a similar medium-long term landscape are numerous. Apart from the key result of restoring a single broadly-based yield curve common to all Eurozone members, the bank-sovereign doom loop would get solved. In fact, the shift to a federal public debt would make obsolete the debate on home bias in the sovereign exposures of Eurozone banks, avoiding to adopt simplistic remedies such the ESBies and the introduction of riskweights and/or exposure limits on Govies. Remedies that greatly underestimate their own implications in terms of discrimination across bonds issued by different governments.

A further benefit would be the upgrading to a much wider and more liquid market of public debt securities than today, and thus also more competitive on international financial markets and able to attract much capitals with a view to

TSee Lanotte et al. (2016) for a thorough critical assessment of the overall desirability of reforming the favorable treatment of banks' sovereign exposures allowed by the current banking supervision prudential rules in Europe. They conclude that the microeconomic and macroeconomic costs of a reform could be sizeable, while the benefits are uncertain. Furthermore, they highlight considerable implementation issues. 
improving the competitiveness of the euro against the other currency blocs on the global playing field.

\section{ESM INSURANCE FUnd, GOVERnMENT DeBt DEFAULT, MORAL HAZARD AND BOND MARKET DISCIPLINE}

In principle risk-sharing benefits from the introduction of insurance schemes can be severely undermined by moral hazard distortions as a result of the risk transfer mechanism from the insured to the insurer party. The argument here can be put in the following simple terms:

1) lower interest costs on debt servicing - as a result of the Insurance Fund guarantee - induce a national government to run higher deficit and thereby increasing its debt leading to higher sovereign risk of default;

2) debt insured by a third party is more likely to trigger outright (strategic) default on the very same debt as the brunt of the cost is borne by the insurer and therefore the insured party gets a free ride.

The first argument basically does not apply to our insurance scheme in that the covenants attached to the debt guarantee forbid the insurance of any form of excess debt. Constraints on admissible deficit (that currently allowed by the Fiscal Compact plus an amount which is equal to the annual premium paid to the ESM in exchange for its guarantee and which is related to the golden rule on investments as explained in the next section) would be binding. Sure enough, the national Government can issue excess debt if it so wishes, but it would have to shoulder the associated higher cost for its credit risk, namely bond market discipline would be fully in operation to guard against fiscal excesses. Well within our framework we could even strengthen the role of bond market discipline if we were to make any excess debt junior vis-à-vis insured debt. In order to better enforce the market discipline, in the above described scenario we also provided for an additional penalty for non-compliant countries: the loss of the ESM guarantee and of the premiums paid up to that time (hence, premiums would remain with the ESM).

Such draconian measures not only would they increase significantly the cost of issuing excess debt but they would also prevent the dilution of the debt guarantee value.

The second argument is more subtle in that the event of default does not hurt investors holding insured debt as the insurer (ESM Insurance Fund) would pay them back in full. Basically, the rogue government can declare default de-facto without "taxing" its bondholders as they are fully reimbursed by the debt insurer. Arguably, even if investors were not damaged by such debt default, they are very likely to become suspicious if the same sovereign borrower were to come again to the market trying to raise funds, of course without any debt 
guarantee (a debt default would disqualify at the outset such government for accessing the ESM Insurance Fund). Hence, the cost of losing market access to new borrowing after default would not differ in practice compared to the case of defaulting with uninsured debt. Anyhow, the fact that the sovereign issuer can avoid "taxing" its bondholders as it declares bankruptcy may weaken, at least to some extent, the incentive to keep on servicing its debt. To contain the impact of such adverse incentive, the ESM covenants should be designed such that a member State in case of default would be required to hit first the portion of debt which does not include risk-sharing clauses; only in the event that such a move would not be enough to overcome its financial troubles, the Stability Mechanism would intervene with its financial resources and would be legitimized to increase its leverage in order to find the funds necessary to cover the losses, including the access to the ECB programs and collateral refinancing policies as above said.

Moreover in order to re-inforce the discipline of the above described mechanism it could be provided the right to recover whatever assets/cashflows have not been settled by the defaulting sovereign State. More specifically, the ESM would become a creditor of the defaulting sovereign State for the amount of funds disbursed to bondholders, net of any sum of money recovered from the defaulting sovereign. Such credit could also be made senior to any other debt owed by the defaulting sovereign. In addition, if the defaulting sovereign were to remain in the EU, a fiscal adjustment program, administered by the Troika, could be included into the package, in order to speed up the residual debt repayment to the ESM. Moreover, if the defaulting sovereign were to leave the Eurozone (Europe) such debt denominated in Euro, would therefore become foreign currency debt for the sovereign debtor because of the prohibition of redenomination on the insured debt. If such foreign currency debt to the ESM - e.g. a European Union Institution - were to be repudiated, then economic sanctions or other form of political pressure can also be envisaged. Ultimately, such very strict ESM covenants would make virtually as costly for the sovereign State to declare default for its insured debt as for its non-insured debt. Not to mention the loss of the incommensurable benefits associated with the shift to a framework based on risk-sharing which on the medium-long term would deliver a convergence across member countries both on the financial and the economic ground, precisely the one required to grant durable stability and well-functioning of any common currency area.

Of course, all these aspects cannot rule out losses for the ESM in case of sovereign default nor can one dismiss altogether the possibility that a defaulting sovereign may end up - willy-nilly - becoming a pariah State in the international community. 


\section{ESM INSURANCE FUND REGULATORY AND ECONOMIC CAPITAL REQUIREMENT}

The Insurance Fund operations require a supporting equity capital which should be financed primarily by retaining and investing insurance premia paid for by sovereign issuers as well as the existing equity capital endowment of the ESM. In principle, the treatment of sovereign risk in the Basel Committee capital framework (Basel II and Basel III) calls for minimum capital requirements commensurate with the underlying credit risk, in line with the objective of ensuring risk sensitivity. In practice, it is well known that there are significant differences in the application of the Basel rules across jurisdictions. In the European Union (EU), authorities have allowed supervisors to permit banks that follow the IRB (Internal Rating Based) approach to stay permanently on the Standardized Approach for their sovereign exposures. In applying the Standardized Approach, in turn, EU authorities have set a zero risk weight not just to sovereign exposures denominated and funded in the currency of the corresponding Member State, but also to such exposures denominated and funded in the currencies of any other Member State ${ }^{\circ}$. Assuming that the current EU authorities provisions were to be applied the Insurance Fund sovereign exposures would not require any additional equity capital. However such provisions are to be (gradually) phased out by 2020 and the sovereign exposures will therefore rely on credit rating agencies' assessments with credit ratings and sovereign risk weights rules as established under the Standardized Approach.

Credit ratings and sovereign risk weights under the Standardised Approach

In per cent

Table B

\begin{tabular}{lcccccc}
\hline Credit ratings & AAA to AA- & $\mathrm{A}+$ to $\mathrm{A}-$ & $\mathrm{BBB}+$ to $\mathrm{BBB}-$ & $\mathrm{BB}+$ to $\mathrm{B}-$ & Below B- & Unrated \\
\hline Risk weight & 0 & 20 & 50 & 100 & 150 & 100 \\
\hline
\end{tabular}

Source: BIS.

Source: BIS (2013), p.11.

Assuming that the current level of credit ratings holds and the pattern of sovereign risk weights implied by the current Basel II-III Standardized Approach it turns out that the regulatory minimum capital requirement would be set at 1.45 percent the notional value of the guaranteed debt. With a total level of public debt that in the Eurozone that could be insured reckoned at around

TThis provision will be phased out gradually between 2017 and 2020. The new framework, governed by the Capital Requirements Directive IV (CRD IV) entered into force since January 2014, supersedes the treatment enshrined in CRD III. It requires that, following the phasingout, the corresponding exposures rely on credit rating agencies' assessments (BIS, 2013, pp10-11). 
10.000 billion, the required minimum regulatory capital would be equal to some 145 billion $^{\circ}$. As explained in our comments on Table 2 regarding the ESM new ESM capital structure, the estimated total cash proceeds raised by the Insurance Fund at the end of the 10 year transition period is reckoned at about 100 billion euro, which would be added to the current paid-in capital of the ESM (just above 80 billion). Even if only partially, current cash capital is held against safe exposures on the assets side (both Cyprus and Spain having already exited from the financial assistance programs granted in the past). Thus, we estimate a foreseeable level of total cushion capital that would be consistent with forthcoming Basel requirements on sovereign exposures. If the Regulator were not satisfied with such level of cushion capital an additional capital buffer, for precautionary reason, may be added on top. This additional capital buffer could be raised from the member countries as additional insurance contributions (equity capital) to be paid out to the ESM, and it would expand the amount of resources that the Fund can raise on the bond market through its routine issuance activity without compromising its target leverage.

TAdditional details on computing ESM regulatory capital requirement are provided in a forthcoming technical appendix to this paper. 


\section{ESM LEVERAge AS KEy dRIVER FOR PROFitABle PROJECT FinANCING to PERIPHERAL COUNTRIES}

Mainstream argument about the need for risk reduction is not wrong at all. The problem is that its supporters pretend that the only way to pursue this goal is to intervene on the numerator of the debt-to-GDP ratio through harsh domestic reforms.

But spending review - especially when applied to economies battered by a prolonged downturn and by the nefarious consequences of risk segregation has a negative impact on growth. In turn, excessive cuts on public spending have perverse effects on the debt-to-GDP ratio simply because the drop in GDP (or its lower growth rate) tends to offset - or even cancel - the progress achieved in terms of public debt reduction.

So far these pro-cyclical effects have been largely ignored by the Eurobureaucracy. The 2011 revision of the Stability and Growth Pact (Six Pact) and the Fiscal Compact signed in March 2012 were introduced - or, better, imposed - by the European institutions in the mistaken belief that fiscal consolidation is the right recipe to increase stability and resilience of the euro area.

Compared with the Maastricht Treaty, the new rules adopted in late 2011 and early 2012 rely on a new fiscal indicator: the structural balance which is defined as the nominal balance net of the cyclical component and one-off measures. The European Commission periodically establishes a country-specific Medium-Term Objective (MTO) in terms of structural balance. In addition, the Fiscal Compact also introduces a fixed ceiling to the structural deficit whose size is linked to the level of the debt-to-GDP ratio.

Yet, structural balance is a theoretical quantity whose estimation comes mainly from the discretionary measurement of the cyclical component which is based on the estimate of the so-called output gap, i.e. the difference between the actual GDP and the potential GDP of an economy. The latter is defined as the output that would be obtained in the hypothesis of full use of the productive factors. No surprise that the evident arbitrariness in the quantification of potential GDP is the subject of an incessant diatribe between peripheral governments and the European Commission, given the important implications for fiscal policy decisions.

These budgetary constraints have forced several governments in the Eurozone to sharply cut public spending, including a large investments' shortfall (Buti and Mohl, 2014, European Central Bank, 2016), despite the golden rule which says that good investments pay off for themselves since they have a fiscal multiplier well above 1 , especially if located in less developed regions (International Monetary Fund, 2014). 
Figure 11 gives an idea of the investments' drop occurred since 2008 and the following reversal of the trends exhibited until that moment (Minenna, 2018). Looking at the total gross fixed capital formation of the 4 larger Eurozone economies (index 100=2010), we see that from 2000 to 2008, investments have experienced a positive trend: actually Germany's performance has not been particularly good until 2005, with a recovery during the period 20062008. But, impressively, after the worst year (2009), Germany has returned to the same path of growth in investments seen prior 2009, as if nothing had happened, and - taking 2010 as reference year - it is now leader across the 4 larger Euro members.

\section{Figure 11 - Gross Fixed Capital Formation - All Sectors (Chain linked volumes, index $2010=100$ )}

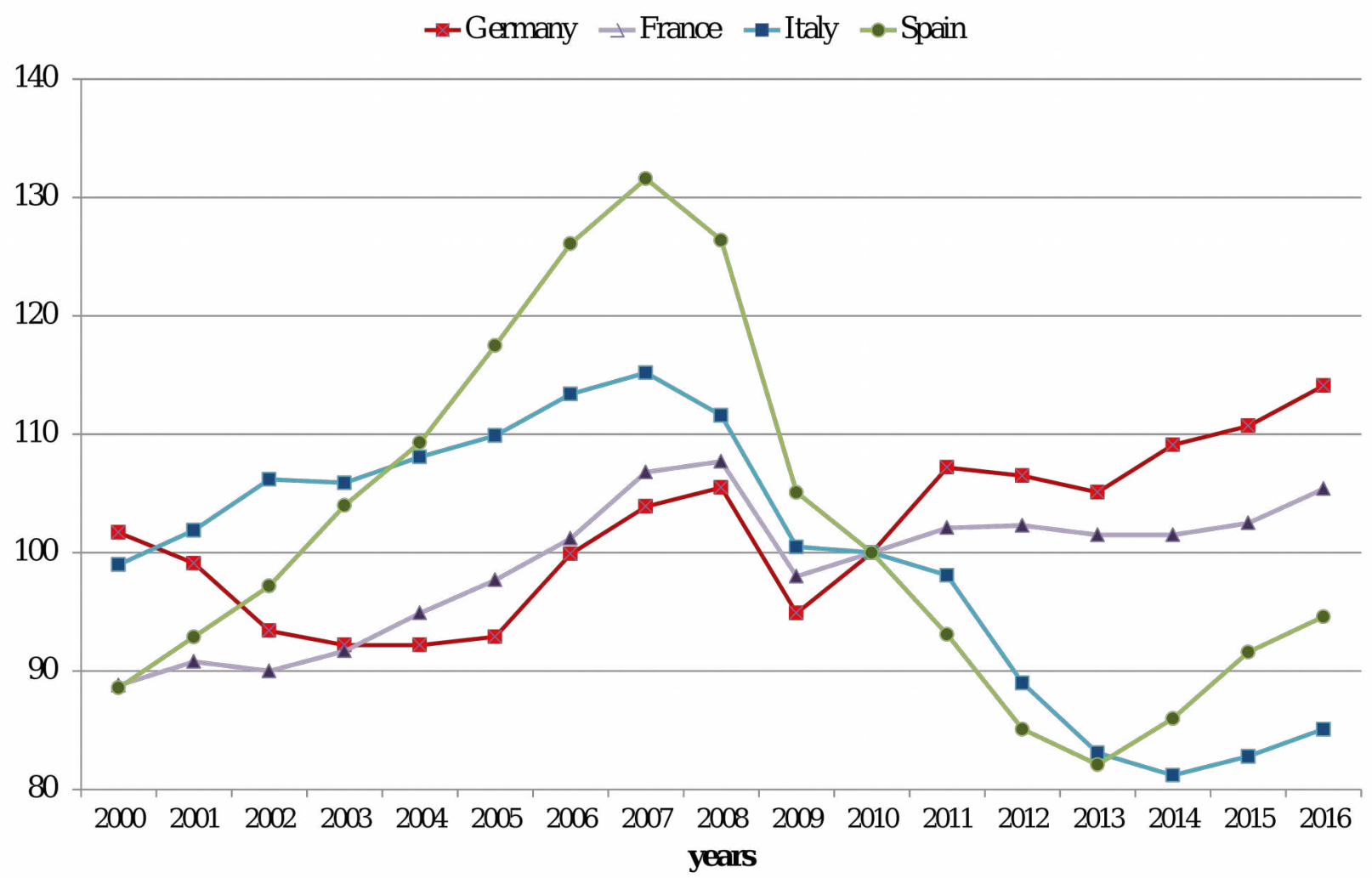

ource: AMECO database

It is worth observing that prior the crisis, leaders were Spain (also due to the mounting real estate speculation) and Italy, the same two countries that still have not fully recovered their past performance, as confirmed by 2016 data below 100 for both.

Figure 12 displays the above described dynamics with regard to the total gross fixed capital formation at current prices (millions of euro), showing the 
overwhelming size of investments in Germany, and also how the crisis and the subsequent tightening of fiscal rules have favored divergent trends between Germany (and, at a lesser extent, France) on the one hand and Italy and Spain on the other hand.

\section{Figure 12 - Gross Fixed Capital Formation - All Sectors (Current prices, EUR Million)}

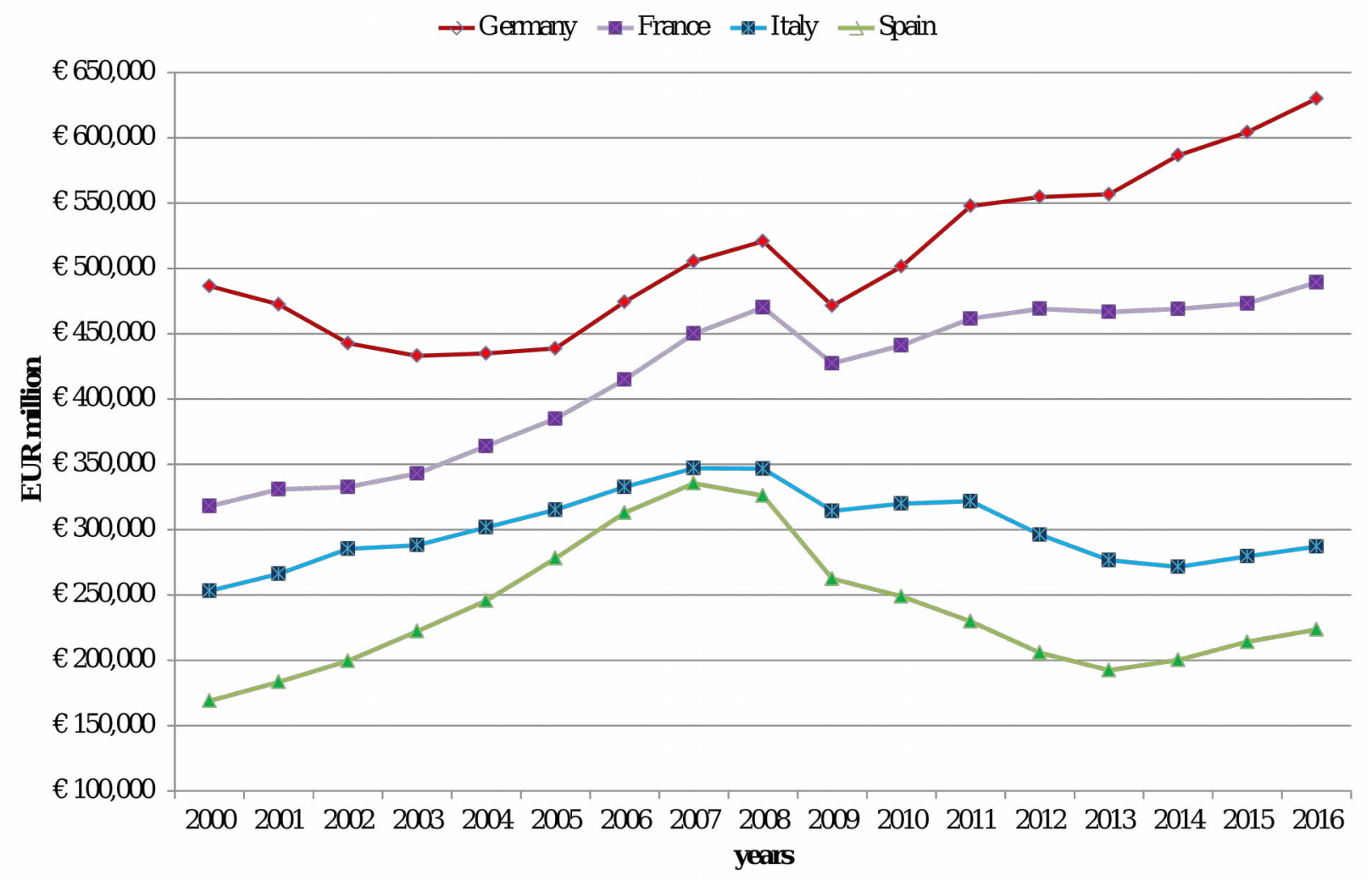

Source: AMECO database

In a recent study (March 2018) Boitani and Pierdichizzi have found that, in times of subdued/recessionary economic performance, positive expenditure shocks tend to have larger fiscal multipliers and to be more effective in boosting aggregate demand than in expansions. Their findings (based on an analysis of the empirical evidence for 12 Euro countries over the period 19852015) also highlight that "expenditure multipliers, in a recession, are larger in high debt/deficit countries than in low debt/deficit countries" and that "in a 
recession fiscal consolidation based on expenditure cuts would have both short and medium rum contractionary effects".

On the light of these arguments we believe that the right way to address the issue of re-aligning the economic cycles of Eurozone countries is to support valuable and safe investment projects within the periphery.

This is the only way to spur growth, also because - despite of the improvements exhibited all over the Eurozone in 2017 - the performances of the different States display a large variability which contrasts with the principle of shared growth and development stated in the EU Treaties and, in some cases, the economic landscape remains quite controversial as well as the robustness of the recovery.

The reformed ESM could prove crucial on this field. Our idea is re-thinking the key destinations of the resources that the Stability Mechanism raises on financial markets, mainly by issuing low-yield securities. Since the establishment in 2012, ESM has used its leverage capability to provide financial assistance to deeply distressed countries, such as Greece and Cyprus. All of these aids were granted taking care of keeping a moderate leverage: the amount of outstanding ESM liabilities is comparable to the paid-in capital of the Mechanism.

We propose to modify the nature of the support programs which benefit from ESM funding without modifying the current low-leverage attitude (apart from the case of extraordinary funding needs related to the activation of its guarantee on sovereign debts). Rather than using money to intervene in overt crisis contexts and pretending beneficiary countries to make strict domestic reforms, the ESM should use those funds in project financing within peripheral countries.

A simple way to realize a similar policy change would be a golden rule set as follows: the Stability Mechanism would have to finance investment plans for the same amount as that paid annually by risky countries to its capital as premiums for the guarantee. If, for example, in a given year the ESM receives new contributions for 10 billion euro from Italy, on the same year it issues 10 billion euro of supranational bonds to fund investments in Italy itself. Of course, this is a simplified example, because in reality the Mechanism would have to carefully manage its assets-liabilities profile in order to balance funding needs and their costs; however, it makes clear the idea that ESM issuing policy should be closely linked to the size of the premiums cashed from guaranteed member countries.

higher real output growth and lower price increases" (Boitani and Pierdichizzi, 2018). 
This would create a strong connection between the financial effort required by the peripheral countries to benefit from the sharing of risks on the public debt and the positive stimulus provided to their economies by the ESM project financing. In addition, since under normal conditions the annual increase in the debt stock could not exceed the amounts currently admitted by the Fiscal Compact plus those allocated to new investments through the support of the ESM, de facto there would be a clear correspondence between greater indebtedness and greater investments, to the benefit of transparency and reputation of the peripheral countries.

With regard to the financial position of the ESM, thanks to the large fiscal multipliers of the investment spending, the Mechanism would get repaid and would also be entitled to receive interesting returns. In order to minimize the likelihood of wastes and malinvestments and preserve a prudential profile, the entire process of projects' selection and ongoing monitoring should be assigned to a European Agency which prospectively could become a EU Minister of Infrastructures and Economic Development. The entire legislative and judiciary apparatus needed to enforce this investment plans - including the law governing procurement/tender procedures and the jurisdiction appointed for litigations - would be defined at the European level without involvement of the country where the project is located.

Figure 13 compares the estimated annual cost of the guarantee paid to ESM with the estimated gross payout of new investments funded with ESM-issued liabilities in the case of Italy, and allows to appreciate the benefit of the proposed reforms in terms to profitable returns on investments in peripheral countries.

\section{Figure 13 - Comparison of the estimated premiums paid to ESM and the estimated Gross Payout of ESM funded investments: ITALY}




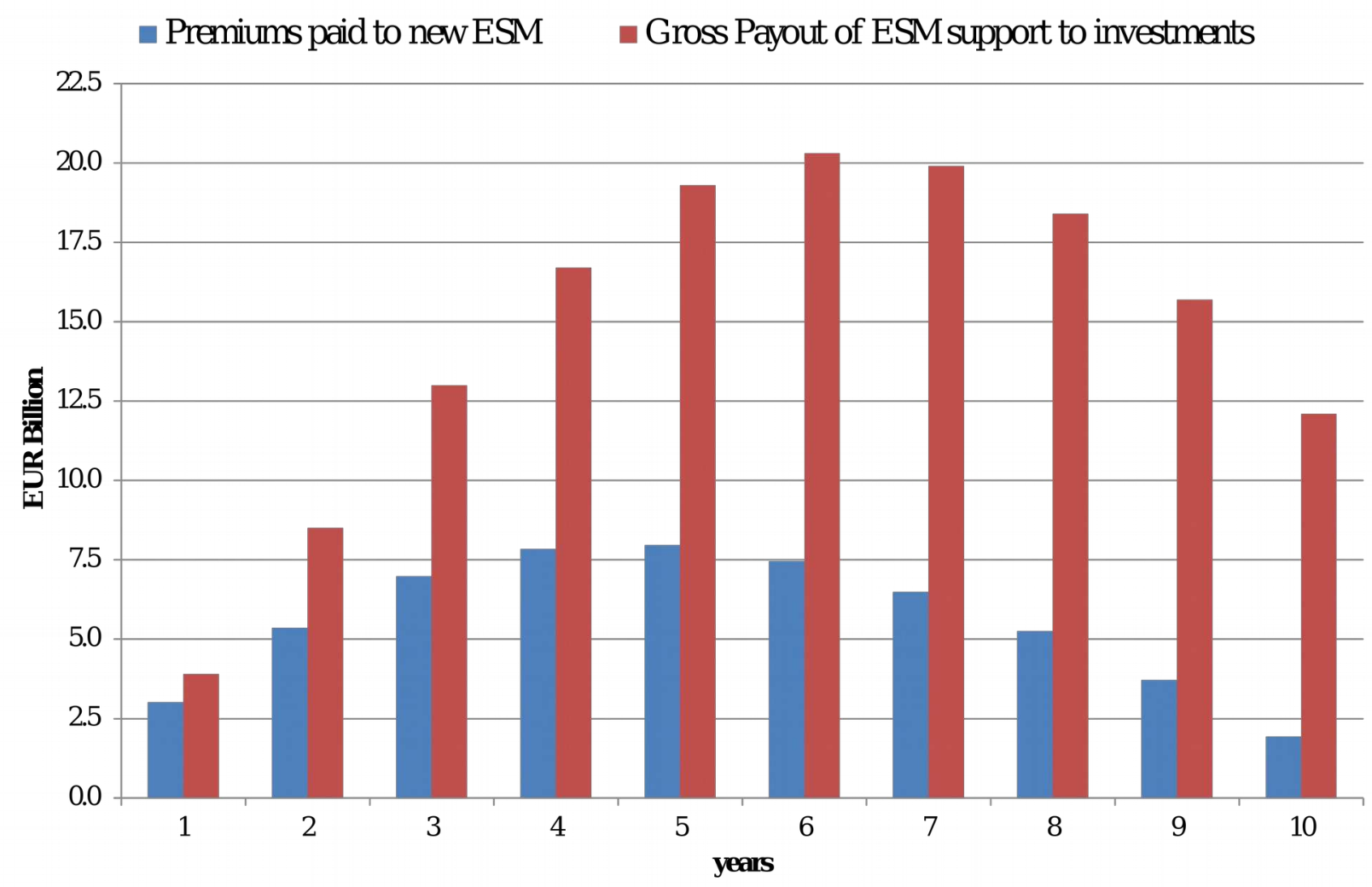




\section{Conclusions}

This work has presented a proposal for Eurozone overhauling that relies on reforms of the European Stability Mechanism. So far the Mechanism has played only a limited emergency role in front of critical episodes related to minor economies or very specific problems (as in the case of Spanish banks). By contrast, several arguments suggest that the current set-up of the Mechanism along with the risk segregation strategy enacted by Germany and its neighbors would make quite unlikely an intervention of the ESM in the event of large shocks hitting major Eurozone members.

Unlike the proposals drawn up by Germany, the European Commission and some French and German economists who continue to see risk segregation and domestic reforms as the only solution to the problems of the peripheral countries, our proposal is based on risk sharing and on supranational facilities to support the recovery of investments in the most fragile economies.

The ESM should turn into a guarantor of the public debts of the different member countries and - in order to preserve market standards and prevent moral hazard to creep into the insurance scheme - it should receive new capital contributions from the countries which get a net benefit from such conditional guarantee in the form of annual insurance premiums valued at fair market price conditions as well as strict covenants attached to the exercise of the debt guarantee. Equity capital contributions to the Insurance Fund would also be based on the incremental risk brought in by each country debt. Such provisions aims at keeping under control the (temporary) increase in the interest expenditure on debt faced by core countries because of the proposed reform. Our insurance scheme challenges the widespread assumption that for a bigger country to provide a guarantee for another sovereign's risk is for taxpayers of the bigger nation to have to shoulder the burden of the borrowing sovereign's excesses (Sinn, 2014, Ch. 8). Although drawing from the recent development in the theory of Eurobonds our proposed Insurance Fund embedded in the ESM it's a genuinely new scheme and an institutional innovation which is not far, with its financial engineering content and structure, from traditional technological innovations which relies on scientific discovery. Thus the argument that "since such Insurance Fund has not been tried before its alleged viability can only be a fluke" must be faulty.

The key implication of our proposed Insurance Fund is the consequent reversal in the expectations of market participants which would lead to the zeroing of sovereign yield spreads, allowing the Eurozone to achieve the ultimate goal of sharing a federal debt with a single yield curve for all of its members, as in the golden age of the European Monetary Union.

The new ESM - by constituting a stable and significant federal budget - would also have a critical mission in reviving large, sustainable and profitable 
investments within peripheral countries whose economic recovery is still uncertain and ailing. This could be achieved through targeted financing of valuable projects and would be an effective way to enact a growth-based risk reduction taking advantage of the high fiscal multiplier of the expenditure in gross fixed capital formation, which was seriously penalized over the last decade. Such ESM support would provide more fragile countries with stronger antibodies to immunize from new shocks and reposition themselves on a durable path of growth. Indeed, only closing the gap between strong-core countries and weak-peripheral countries would make the shift to a common public debt sustainable on the medium-long term the better answer to the neoliberal argument that pretends all problems, differences and unbalances of the Euro area being exclusively due to fiscal profligacy of the periphery rather than to the Eurozone incompleteness and the undue discrepancies delivered by persisting risk segregation.

With respect to the status quo - where risk nationalizations are prevailing and consequently the European Monetary Union is moving towards a fixedexchange rate regime - our proposal would deliver peripheral countries a significant benefit both in terms of default probabilities and in terms of expected losses and would support the financial system with a notional amount of safe-assets compatible with its needs and consequently able to free the potential of the industrial system.

Table 3 here below summarizes the main pros and cons of our proposal adopting the standpoint of a comparative statics' analysis.

\section{Table 3 - Summary of the main pros and cons of the proposed ESM reform}

\begin{tabular}{|l|l|}
\hline \multicolumn{1}{|c|}{ Pros Cons } \\
\hline $\begin{array}{l}\text { The Eurozone sovereigns' bailout Fund would } \\
\text { become, through a gradual process which is } \\
\text { compliant with market logics, the guarantor } \\
\text { of the Eurozone public debt. }\end{array}$ & $\begin{array}{l}\text { During the convergence } \\
\text { process core countries would } \\
\text { see interest spending on } \\
\text { public debt increase. }\end{array}$ \\
\hline $\begin{array}{l}\text { Elimination of redenomination risk: the debt } \\
\text { guaranteed by the Insurance Fund would be } \\
\text { subject to the prohibition of conversion into } \\
\text { another currency }\end{array}$ \\
\hline $\begin{array}{l}\text { Reduction of moral hazard gains that a } \\
\text { member country could achieve by leaving } \\
\text { the Eurozone }\end{array}$ \\
\hline $\begin{array}{l}\text { Elimination of yield spreads between } \\
\text { government bonds issued by the different } \\
\text { EMU member countries }\end{array}$ \\
\hline
\end{tabular}




\begin{tabular}{|c|c|}
\hline $\begin{array}{l}\text { Creation of a Eurozone safe asset with an } \\
\text { outstanding notional appropriate to the } \\
\text { needs of the economic and financial system } \\
\text { of the Euro-area }\end{array}$ & \\
\hline $\begin{array}{l}\text { Elimination of the phenomenon of negative } \\
\text { interest rates and its known consequences } \\
\text { on pension funds and, more generally, on } \\
\text { the profitability of the financial system }\end{array}$ & \\
\hline $\begin{array}{l}\text { Normalization of the existing unbalances on } \\
\text { the Target2 system }\end{array}$ & \\
\hline $\begin{array}{l}\text { Adoption of a golden rule for public } \\
\text { investments }\end{array}$ & \\
\hline $\begin{array}{l}\text { Elimination of the callable shares envisaged } \\
\text { by the current ESM financial structure }\end{array}$ & \\
\hline $\begin{array}{l}\text { In place of callable shares, the European } \\
\text { Stability Mechanism Fund would be } \\
\text { recapitalized at the expense of the member } \\
\text { countries whose sovereign risk exceeds the } \\
\text { Eurozone average }\end{array}$ & \\
\hline $\begin{array}{l}\text { Use of market pricing techniques for the } \\
\text { creation of the financial structure of the } \\
\text { Insurance Fund }\end{array}$ & \\
\hline $\begin{array}{l}\text { Provision of a 10-year or more transition } \\
\text { period for the creation of: } \\
\text { 1. a Eurozone public debt, } \\
\text { 2. Eurobonds, } \\
\text { 3. a federal budget of adequate size, } \\
\text { 4. a European harmonized framework for } \\
\text { the management of contracts and } \\
\text { litigations }\end{array}$ & \\
\hline $\begin{array}{l}\text { Eased tapering: the deflation of the assets' } \\
\text { side of the ECB balance sheet for the part } \\
\text { represented by the government bonds } \\
\text { purchased with Quantitative Easing would be } \\
\text { made easier by the sounder marketability } \\
\text { environment of such bonds arising from the } \\
\text { ESM guarantee }\end{array}$ & \\
\hline
\end{tabular}

In synthesis this proposal would lay the foundations for an organic and harmonic development of the United States of Europe as prescribed in the European Treaties. 


\section{References,}

Baglioni, A., Cherubini, U., (2011), A Theory of Eurobonds, http://ssrn.com/abstract $=1928573$.

Baglioni, A., Cherubini, U.,.(2016), Eurobonds: A Quantitative Approach, Review of Law \& Economics,

Basu, K., Stiglitz, J., (2015), Sovereign Debt and Joint Liability: An Economic Theory Model for Amending the Treaty of Lisbon, 125 The Economic Journal F115-F130.

Balassone et al. (2016), Economic Governance in The Euro Area: Balancing Risk Reduction and Risk Sharing, Banca d'Italia, Occasional papers, n.344.

Beetsma, R., Mavromatis, K., (2014), An Analysis of Eurobonds, Journal of International Money and Finance, 45, 91-111.

Bénassy-Quéré, A., et al., (2018), Reconciling risk sharing with market discipline: A constructive approach to euro area reform, CEPR Policy Insight No. 91.

BIS (2017), Statistical Release: OTC Derivatives Statistics at End-June 2017, Basel.

Blyth, M., (2013), Austerity: The History of a Dangerous Idea, Oxford 2013.

Bofinger P., (2018), Euro area reform: No deal is better than a bad deal, VoxEU.org, 15 May.

Boitani, A, Pierdichizzi, S., (2018), Public Expenditure Multipliers in recessions. Evidence from the Eurozone, Working Paper n. 68, March 2018, Università Cattolica del Sacro Cuore - Dipartimento di Economia e Finanza

Boonstra, W.W. (2010), The Creation of a Common European Bond Market, Cahier Comte Boël, No. 14, ELEC, April.

Brunnermeier, M., et al., (2016), ESBies: Safety in the tranches, Working Paper Series, No 21 / September 2016, European Systemic Risk Board

Bundesbank, (2017), Deutsche Bundesbank Monatbericht, Juli 2017, https://www. bundesbank.de/Redaktion/DE/Downloads/Veroeffentlichungen/Mon atsberichtsaufsaetze/2017/2017_07_zinsausgaben.pdf?_blob=publicationFile

Buti, M., Mohl, P., (2014), Lacklustre investment in the Eurozone: Is there a puzzle?, https://voxeu.org/article/raising-investment-eurozone

Canziani P., Giavazzi, F., Manasse, P., Tabellini, G., (1994), Fiscal Rule and Debt Sustainability: History and Institutions, in Bond Market, Treasury and Debt Management, The Italian Case, Chapman \& Hall, London 
Delpla J., Weizsacker, J., (2010), The blue bond proposal, Bruegel Policy Brief 2010-/03.

Cherubini, U., Violi, R., (2015), Government Bonds Ammunitions for the ECB Quantitative Easing, University of Bologna, https://papers.ssrn.com/sol3/papers.cfm?abstract id $=2560798$

Claessens, S., Mody, A., Vallée, S., (2012), Paths to Eurobonds, IMF Working Paper WP/12/172.

Curto, J. D., Nunes, J.P., Oliveira, L., (2012), The determinants of sovereign credit spread changes in the Eurozone, Journal of International Financial Markets, Institutions and Money, Volume 22, Issue 2, Pages 278-304

De Grauwe, P. (2013), Design Failures in the Eurozone: Can they be fixed?, LSE ‘Europe in Question' Discussion Paper Series

De Grauwe, P., Moesen, W,. (2009), Gains for All: a Proposal for a Common Euro Bond, Intereconomics, May/June, pp.132 - 135.

De Grauwe, P., Ji, Y., (2013), Self-fulfilling crises in the Eurozone: An empirical test, Journal of International Money and Finance, Volume 34, April 2013, Pages 15-36

De Grauwe, P., (2015), Design failures of the Eurozone, VoxEU.org, 7 September.

De Santis, R.A., (2015), A Measure of Redenomination Risk, Working Paper Series No. 1785, European Central Bank. https://www.ecb.europa.eu/pub/pdf/scpwps/ecbwp1785.en.pdf.

Di Cesare, A., Grande, G., Manna, M. and Taboga, M., (2012), Recent Estimates of Sovereign Risk Premia for Euro-Area Countries, Bank of Italy Occasional Paper, No. 128.

Eijffinger, S.C.W. (2010), Legislative proposals on EU economic governance: what is missing within and beyond?, Briefing Paper for the Monetary Dialogue of the European Parliament with the President of the European Central Bank, European Parliament, Brussels.

ESM, (2018), 2017 Annual Report, Luxembourg, www.esm.europa.eu.

Esteves, R.P., Tuncer, A.C., (2016), Eurobonds Past and Present: A Comparative Review on Debt Mutualization in Europe, Review of Law \& Economics, vol. 12, n. 3.

Euro Area Member States, (2012), Treaty Establishing the European Stability Mechanism, https://www.esm.europa.eu/legal-documents/esm-treaty 
European Central Bank, (2016), Public investment in Europe

European Commission, (2011), Green Paper on the feasibility of introducing Stability Bonds

European Commission, (2018), Proposal for a regulation: Sovereign bond-back securities product regulation, https://ec.europa.eu/info/law/betterregulation/initiatives/com-2018-339_en

European Stability Mechanism, (2018), ESM Annual Report 2017, https://www.esm.europa.eu/publications/esm-annual-report-2016

Euro-nomics Group, (2011), European Safe Bonds (ESBies), http://personal.Ise.ac.uk/vayanos/euronomics/esbies.pdf

Favero, C., Missale, A., (2012), Sovereign Spreads in the Euro Area. Which Prospects for a Eurobond?, Economic Policy, 27, pp. 231-273..

Furceri, D., Zdzienicka, A., (2013), The Euro Area Crisis: Need for a Supranational Fiscal Risk Sharing Mechanism?, IMF Working Paper, WP/13/198

Finance Ministers of 7 North Eurozone countries, (2018), Position Paper on EMU architecture,

https://www. dutchnews.nl/wpcms/wpcontent/uploads/2018/03/PositionEMUDen markEstoniaFinlandIrelandLatviaLithuaniatheNetherlandsandSweden.pdf

German Council of Economic Experts, (2016), A Mechanism to Regulate Sovereign Debt Restructuring in the Euro Area, Working Paper 04/2016

Godley, W., (1997), Curried EMU - the meal that fails to nourish, Observer, August $31^{\text {st }}$, p. 24

Goodhart, C., (1997), One government, one money, Prospect Magazine, March 1997.

Gros, D., Micossi, S., (2009), A Bond-Issuing Stability Fund Could Rescue Europe, in «Europe's World», Spring.

Herr, H., Priewe, J., Watt, A., (2017), Saving The Euro: Redesigning Euro Area Economic Governance, Social Europe Publishing

loannou, D., Schäfer, D., (2017), Risk sharing in EMU: key insights from a literature review, SUERF Policy Note, Issue No 21

International Monetary Fund, (2014), Is it time for an infrastructure push? The macroeconomic effects of public investment, World Economic Outlook, Chapter 3 
Lanotte, M., Manzelli, G., Rinaldi, A. M., Taboga, M. and Tommasino, P., (2016), Easier Said than Done? Reforming the Prudential Treatment of Banks' Sovereign Exposures, Bank of Italy Occasional Paper, No. 326.

Lhabitant, F-S., (2015), Handbook of hedge Funds, Wiley Online Library, https://onlinelibrary.wiley.com/doi/book/10.1002/9781119202028

Milano, V., Reichlin, P., (2017), Risk sharing across the US and EMU: the role of public institutions, LUISS School of European Political Economy, POLICY BRIEF, January 9, 2017

Minenna, M., (2014), Control the spread, Risk Magazine, October issue

Minenna, M., (2016), The Incomplete Currency, Wiley

Minenna, M., (2017), Why ESBies won't solve the euro area's problems, FT Alphaville, https://ftalphaville.ft.com/2017/04/25/2187829/guest-post-whyesbies-wont-solve-the-euro-areas-problems/

Minenna, M., (2018), Understanding the differences between German and Italian investment spending, FT Alphaville, https://ftalphaville.ft.com/2018/03/27/2199381/guest-post-understanding-thedifferences-between-german-and-italian-investment-spending/

Minenna, M., Aversa, D., (2018), A revised European Stability Mechanism to realize risk sharing on public debts at market conditions and realign economic cycles in the Euro area, Economic Notes by John Wiley \& Sons, Ltd, volume 9999, no. 999-2018: pp. 1-19

Monti, M. (2010), Report to the President of the European Commission, May 2010.

Oehmke M., Zawadowski, A., (2017), The Anatomy of the CDS Market, The Review of Financial Studies, vol. 30 n.1, pp. 80-119.

Pennacchi, G.G., (2009), Deposit Insurance, AEI Conference on Private Markets and Public Insurance Programs

Semmler, W., Young, B., (2017), Re-Booting Europe: What kind of Fiscal Union What kind of Social Union? The New School for Social Research, Working Paper $13 / 2017$.

Sinn, H. W., (2014), The Euro Trap: On Bursting Bubbles, Budgets, and Beliefs, Oxford University Press, Oxford.

Tremonti, G., Juncker, J.C., (2010), E-bonds would end the crisis, The Financial Times, 5 December. 
